Article

\title{
Considerations on the Rational Design of Covalently Conjugated Cell-Penetrating Peptides (CPPs) for Intracellular Delivery of Proteins: A Guide to CPP Selection Using Glucarpidase as the Model Cargo Molecule
}

\author{
Yasaman Behzadipour ${ }^{1}$ and Shiva Hemmati ${ }^{1,2,3, *(1)}$ \\ 1 Department of Pharmaceutical Biotechnology, School of Pharmacy, Shiraz University of Medical Sciences, \\ Shiraz 71345-1583, Iran; yasaman_behzadipour@yahoo.com \\ 2 Biotechnology Research Center, Shiraz University of Medical Sciences, Shiraz 71345-1583, Iran \\ 3 Pharmaceutical Sciences Research Center, Shiraz University of Medical Sciences, Shiraz 71345-1583, Iran \\ * Correspondence: hemmatish@sums.ac.ir; Tel.: +98-71-3242-4128
}

Received: 6 November 2019; Accepted: 16 November 2019; Published: 26 November 2019

\begin{abstract}
Access of proteins to their intracellular targets is limited by a hydrophobic barrier called the cellular membrane. Conjugation with cell-penetrating peptides (CPPs) has been shown to improve protein transduction into the cells. This conjugation can be either covalent or non-covalent, each with its unique pros and cons. The CPP-protein covalent conjugation may result in undesirable structural and functional alterations in the target protein. Therefore, we propose a systematic approach to evaluate different CPPs for covalent conjugations. This guide is presented using the carboxypeptidase G2 (CPG2) enzyme as the target protein. Seventy CPPs — out of 1155 - with the highest probability of uptake efficiency were selected. These peptides were then conjugated to the $\mathrm{N}$ - or $\mathrm{C}$-terminus of CPG2. Translational efficacy of the conjugates, robustness and thermodynamic properties of the chimera, aggregation possibility, folding rate, backbone flexibility, and aspects of in vivo administration such as protease susceptibility were predicted. The effect of the position of conjugation was evaluated using unpaired t-test $(p<0.05)$. It was concluded that $\mathrm{N}$-terminal conjugation resulted in higher quality constructs. Seventeen CPP-CPG2/CPG2-CPP constructs were identified as the most promising. Based on this study, the bioinformatics workflow that is presented may be universally applied to any CPP-protein conjugate design.
\end{abstract}

Keywords: cell-penetrating peptides; computational drug design; peptide-based drug delivery; therapeutic peptide-protein; bioconjugation; biomacromolecules; protein delivery; carboxypeptidase G2

\section{Introduction}

Biotherapeutics such as protein-based therapeutics are a fast-growing group of pharmaceuticals [1]. Although the advantage of biotherapeutics is their target specificity, one of the major challenges in the way of further development of protein-based therapeutics is their intracellular delivery. A huge hydrophilic proteinaceous macromolecule cannot cross the hydrophobic lipid bilayer membrane surrounding a cell [2]. This obstacle, however, can be overcome with the assistance of a cell-penetrating peptide (CPP).

CPPs are short relatively non-toxic peptide sequences, usually less than 30 amino acids, which not only have the ability to cross cellular membranes, but also can co-transport a variety of biologically active molecules (cargoes) inside the cells [1,2]. Since their discovery in 1988, a wide range of different CPPs has been identified and subjected to clinical trial studies [3,4]. Chemically, CPPs are 
categorized into three classes, known as cationic, hydrophobic, and amphipathic. Cationic CPPs have positively charged residues that are capable of interacting with negatively charged groups on the cellular membrane, which results in their internalization [5]. Hydrophobic CPPs have mainly nonpolar residues that can interact with the hydrophobic segments of the membrane [6]. Despite the presence of both polar and non-polar residues in amphipathic CPPs, some non-amphipathic peptides can display amphipathic behavior after folding into $\alpha$-helices or $\beta$-sheets [7].

Considering CPPs as appropriate delivery vectors for proteinaceous therapeutics [8], two main strategies are available to enable CPPs for the co-transportation of the desired cargo molecules across the plasma membrane. These systems might be designed in the form of covalent conjugation of the CPP and the cargo molecule or as a non-covalent complex of CPP and cargo [9]. Covalent conjugation can be established using chemical synthesis methods [10-12]. However, for protein or peptide cargos, covalent conjugation to CPPs can be accomplished by expressing the chimeric gene in bacterial expression systems such as E. coli $[13,14]$.

There are some other limitations and challenges regarding protein-based therapeutics, such as low solubility, short half-life, and the induction of unwanted or fatal allergic and immunological responses in the recipients. For engineered CPP-protein conjugates, wherein new amino acid orders are added to the target protein, some further issues in addition to the above-mentioned challenges must be addressed, including incorrect folding of the engineered protein, changes in 3D structures and backbones, and variations in the side chains that stabilize the structure $[15,16]$.

Although more than one thousand experimentally validated CPPs have been identified [17], a universal method to discriminate between CPPs and designate the ideal peptide for a conjugation is not currently available. Arbitrarily selecting a frequently used CPP might not necessarily result in the design of an optimal bio-conjugate [18]. Therefore, in the covalent conjugation of CPPs to a protein, there are several issues that still need to be addressed in the process of CPP selection, including: (1) consideration of CPPs that provide a higher penetration of the conjugate; (2) evaluating the degree of CPP interference with the stereochemistry of the conjugate; (3) pondering CPPs with higher solubility and stability in the production and formulation process; (4) assessing CPPs that do not result in the aggregation of the cargo after delivery; and (5) inspecting the degree of potential allergenicity, protease sensitivity, and hemolysis of the conjugate. Hence, devising a realistic workflow to follow the aforementioned criteria in the selection process of the appropriate CPP is one of the most influential factors affecting the structural and functional properties of the target protein.

Using a guideline considering computational approaches in the rational design of a chimera would provide the opportunity to envisage part of the abovementioned criteria and attain a comprehensible understanding of the protein's characteristics $[19,20]$. Herein, the credit goes to the improvement in the software or web-based portals with strong algorithms that determine the structure of the conjugates and predict the in vivo effects of the chimera.

Therefore, we propose a bioinformatics guideline using some already existing in silico methods to select the best CPP candidates in conjugation with carboxypeptidase G2 (CPG2) enzyme as the model cargo molecule. CPG2 also known as glucarpidase (Voraxaz ${ }^{\circledR}$ ) is an FDA-approved bacterial enzyme breaking methotrexate (MTX) down into two noncytotoxic metabolites [21-23]. Due to its capacity for hydrolyzing a wide range of folate analogs, CPG2 is also able to convert non-toxic glutamated nitrogen mustard prodrugs into cytotoxic substances; hence, it is proposed as an intriguing choice for the antibody/gene-directed enzyme prodrug therapy modalities known as ADEPT and GDEPT, respectively [24-26]. In glucarpidase therapy, the enzyme only reduces the circulating MTX levels and has no access to the drug inside the cells. Therefore, there is a rebound of MTX into the blood due to the release of intracellular stored MTX [27]. Accordingly, it seems reasonable to deliver the CPG2 enzyme to the intracellular compartment. Through experimental studies, we have recently achieved the intracellular delivery of CPG2 in conjugation with the well-known transcription transactivator protein of HIV-1 (TAT) peptide [28]. Therefore, CPG2 has been used as the model cargo in the preparation of the current investigation. 
Table 1. Results of CPPred-RF server analysis for 70 cell-penetrating peptides (CPPs) that had high uptake efficiency with prediction confidence of above 0.9.

\begin{tabular}{|c|c|c|c|c|c|c|}
\hline Peptide No. & CPPs' Names & Amino Acid Sequence & $\begin{array}{c}\text { Cell-Penetrating } \\
\text { or Not }\end{array}$ & $\begin{array}{c}\text { Prediction } \\
\text { Confidence } \\
{ }^{1}\end{array}$ & $\begin{array}{l}\text { Uptake } \\
\text { Efficiency }\end{array}$ & $\begin{array}{c}\text { Prediction } \\
\text { Confidence }^{2}\end{array}$ \\
\hline 1 & Transportan 10 (TP10) & AGYLLGKINLKALAALAKKIL & Cell-penetrating & 0.98 & High & 1.00 \\
\hline 2 & Ala43 substitution mutant of pAntp (43-58) & AQIKIWFQNRRMKWKK & Cell-penetrating & 0.95 & High & 0.96 \\
\hline 3 & Crot (27-39) derivative 1 & CRFRFKCCKK & Cell-penetrating & 0.96 & High & 0.98 \\
\hline 4 & Crot (27-39) derivative 2 & CRFRWKCCKK & Cell-penetrating & 0.96 & High & 0.99 \\
\hline 5 & Crot (27-39) derivative 3 & CRWRFKCCKK & Cell-penetrating & 0.96 & High & 1.00 \\
\hline 6 & CyLoP-1 & CRWRWKCCKK & Cell-penetrating & 0.95 & High & 1.00 \\
\hline 7 & Crot (27-39) derivative 4 & CRWRWKCGCKK & Cell-penetrating & 0.92 & High & 0.99 \\
\hline 8 & Crot (27-39) derivative 5 & DCRWRWKCCKK & Cell-penetrating & 0.82 & High & 0.99 \\
\hline 9 & pAntp (49-58) & FQNRRMKWKK & Cell-penetrating & 0.84 & High & 0.91 \\
\hline 10 & Tat $(48-60)$ & GRKKRRQRRRPPQ & Cell-penetrating & 0.97 & High & 0.94 \\
\hline 11 & pAntp (45-58) & IKIWFQNRRMKWKK & Cell-penetrating & 0.93 & High & 0.91 \\
\hline 12 & Bip15 & IPMLK & Cell-penetrating & 0.56 & High & 0.92 \\
\hline 13 & pAntp (47-58) & IWFQNRRMKWKK & Cell-penetrating & 0.89 & High & 0.97 \\
\hline 14 & II & KALAALLKKLAKLLAALK & Cell-penetrating & 1.00 & High & 0.93 \\
\hline 15 & Crot (27-39) derivative 6 & KCCKWRWRCK & Cell-penetrating & 0.95 & High & 0.94 \\
\hline 16 & Crot (27-39) derivative 7 & KCGCRWRWKCGCKK & Cell-penetrating & 0.95 & High & 0.90 \\
\hline 17 & Crot (27-39) derivative 8 & KCRWRWKCCKK & Cell-penetrating & 0.95 & High & 0.98 \\
\hline 18 & Crot (27-39) derivative 9 & KDCRWRWKCCKK & Cell-penetrating & 0.78 & High & 0.99 \\
\hline 19 & pAntp (46-58) & KIWFQNRRMKWKK & Cell-penetrating & 0.93 & High & 0.96 \\
\hline 20 & 7 & KLWMRWWSPTTRRYG & Cell-penetrating & 0.98 & High & 0.93 \\
\hline 21 & No.14-2 & KLWMRWYSATTRRYG & Cell-penetrating & 0.98 & High & 0.97 \\
\hline 22 & No.14 & KLWMRWYSPTTRRYG & Cell-penetrating & 0.98 & High & 0.96 \\
\hline 23 & No.14-7 & KLWMRWYSPWTRRYG & Cell-penetrating & 0.96 & High & 0.92 \\
\hline 24 & Crot (27-39) & KMDCRWRWKCCKK & Cell-penetrating & 0.80 & High & 0.94 \\
\hline 25 & Crot (27-39) derivative 10 & KMDCRWRWKCKK & Cell-penetrating & 0.78 & High & 0.95 \\
\hline 26 & Crot (27-39) derivative 11 & KMDCRWRWKCSKK & Cell-penetrating & 0.82 & High & 0.95 \\
\hline 27 & Crot (27-39) derivative 12 & KMDCRWRWKSCKK & Cell-penetrating & 0.83 & High & 0.95 \\
\hline 28 & pVEC mutant 1 & LLIILRARIRKQAHAHSK & Cell-penetrating & 0.98 & High & 0.90 \\
\hline 29 & pVEC mutant 2 & LLIILRRAIRKQAHAHSK & Cell-penetrating & 0.98 & High & 0.95 \\
\hline 30 & pVEC mutant 3 & LLIILRRRIRAQAHAHSK & Cell-penetrating & 0.98 & High & 0.94 \\
\hline 31 & Crot (27-39) derivative 13 & MDCRWRWKCCKK & Cell-penetrating & 0.79 & High & 0.93 \\
\hline 32 & $\operatorname{ARF}(1-22)$ & MVRRFLVTLRIRRACGPPRVRV & Cell-penetrating & 0.88 & High & 0.93 \\
\hline 33 & M918 & MVTVLFRRLRIRRACGPPRVRV & Cell-penetrating & 0.90 & High & 0.94 \\
\hline 34 & pAntp (51-58) & NRRMKWKK & Cell-penetrating & 0.90 & High & 0.91 \\
\hline 35 & pAntp $(44-58)$ & QIKIWFQNRRMKWKK & Cell-penetrating & 0.96 & High & 0.92 \\
\hline
\end{tabular}


Table 1. Cont.

\begin{tabular}{|c|c|c|c|c|c|c|}
\hline Peptide No. & CPPs' Names & Amino Acid Sequence & $\begin{array}{c}\text { Cell-Penetrating } \\
\text { or Not }\end{array}$ & $\begin{array}{c}\text { Prediction } \\
\text { Confidence }\end{array}$ & $\begin{array}{l}\text { Uptake } \\
\text { Efficiency }\end{array}$ & $\begin{array}{c}\text { Prediction } \\
\text { Confidence }^{2}\end{array}$ \\
\hline 36 & pAntp (50-8) & QNRRMKWKK & Cell-penetrating & 0.88 & High & 0.96 \\
\hline 37 & Ala44 substitution mutant of pAntp (43-58) & RAIKIWFQNRRMKWKK & Cell-penetrating & 1.00 & High & 0.99 \\
\hline 38 & PDX -1-PTD & RHIKIWFQNRRMKWKK & Cell-penetrating & 0.99 & High & 0.92 \\
\hline 39 & No.14-25 & RLFMRFYSPTTRRYG & Cell-penetrating & 0.95 & High & 0.93 \\
\hline 40 & No.14-17 & RLWMRWASPTTRRYG & Cell-penetrating & 0.99 & High & 0.96 \\
\hline 41 & No.14-18 & RLWMRWYAPTTRRYG & Cell-penetrating & 0.98 & High & 0.98 \\
\hline 42 & No.14-20 & RLWMRWYSPATRRYG & Cell-penetrating & 0.99 & High & 1.00 \\
\hline 43 & No.14-21 & RLWMRWYSPTARRYG & Cell-penetrating & 0.99 & High & 1.00 \\
\hline 44 & No.14-35 & RLWMRWYSPTTRRYA & Cell-penetrating & 0.98 & High & 0.98 \\
\hline 45 & No.14-1 & RLWMRWYSPTTRRYG & Cell-penetrating & 0.99 & High & 0.98 \\
\hline 46 & 30 & RLYMRYYSPTTRRYG & Cell-penetrating & 0.97 & High & 0.93 \\
\hline 47 & Ala45 substitution mutant of pAntp (43-58) & RQAKIWFQNRRMKWKK & Cell-penetrating & 0.98 & High & 0.98 \\
\hline 48 & Ala46 substitution mutant of pAntp (43-58) & RQIAIWFQNRRMKWKK & Cell-penetrating & 0.98 & High & 0.91 \\
\hline 49 & Ala47 substitution mutant of pAntp (43-58) & RQIKAWFQNRRMKWKK & Cell-penetrating & 0.99 & High & 0.99 \\
\hline 50 & Ala48 substitution mutant of pAntp (43-58) & RQIKIAFQNRRMKWKK & Cell-penetrating & 1.00 & High & 0.94 \\
\hline 51 & Ala49 substitution mutant of pAntp (43-58) & RQIKIWAQNRRMKWKK & Cell-penetrating & 1.00 & High & 0.98 \\
\hline 52 & Ala50 substitution mutant of pAntp (43-58) & RQIKIWFANRRMKWKK & Cell-penetrating & 0.99 & High & 0.99 \\
\hline 53 & pAntpHD (Pro50) & RQIKIWFPNRRMKWKK & Cell-penetrating & 0.99 & High & 0.96 \\
\hline 54 & Ala51 substitution mutant of pAntp (43-58) & RQIKIWFQARRMKWKK & Cell-penetrating & 0.99 & High & 0.94 \\
\hline 55 & Ala52 substitution mutant of pAntp (43-58) & RQIKIWFQNARMKWKK & Cell-penetrating & 0.95 & High & 0.92 \\
\hline 56 & Met-Arg & RQIKIWFQNMRRKWKK & Cell-penetrating & 1.00 & High & 0.93 \\
\hline 57 & Ala54 substitution mutant of pAntp (43-58) & RQIKIWFQNRRAKWKK & Cell-penetrating & 0.99 & High & 0.97 \\
\hline 58 & Penetratin & RQIKIWFQNRRMKWKK & Cell-penetrating & 1.00 & High & 0.97 \\
\hline 59 & Retro - Tat (57-49) & RRRQRRKKR & Cell-penetrating & 1.00 & High & 0.90 \\
\hline 60 & R6 & RRRRRR & Cell-penetrating & 1.00 & High & 0.91 \\
\hline 61 & R9 & RRRRRRRRR & Cell-penetrating & 1.00 & High & 0.91 \\
\hline 62 & Crot (27-39) derivative 14 & RWRWKCCKK & Cell-penetrating & 0.91 & High & 0.97 \\
\hline 63 & Crot (27-39) derivative 15 & SRWRWKCCKK & Cell-penetrating & 0.94 & High & 0.93 \\
\hline 64 & $\operatorname{Rev}(34-50)$ & TRQARRNRRRRWRERQR & Cell-penetrating & 0.98 & High & 0.90 \\
\hline 65 & HIV-1 Rev (34-50) & TRQARRNRRRRWRERQRGC & Cell-penetrating & 0.96 & High & 0.90 \\
\hline 66 & Bip6 & VPALK & Cell-penetrating & 0.74 & High & 0.96 \\
\hline 67 & Bip1 & VPMLK & Cell-penetrating & 0.57 & High & 0.96 \\
\hline 68 & Bip2 & VPTLK & Cell-penetrating & 0.67 & High & 0.99 \\
\hline 69 & Bip16 & VPTLQ & Cell-penetrating & 0.60 & High & 0.91 \\
\hline 70 & pAntp (48-58) & WFQNRRMKWKK & Cell-penetrating & 0.84 & High & 0.97 \\
\hline
\end{tabular}

${ }^{1}$ Prediction confidence of cell penetration. ${ }^{2}$ Prediction confidence of uptake efficiency. 
Within this study, we describe significant factors affecting CPP-CPG2 recombinant conjugate and will introduce a guideline for the design of CPP-protein conjugates. This instruction would provide a workflow using available bioinformatics tools to design an effective biotherapeutic with the optimum pharmacological responses and the fewest side effects. It is expected that this guideline will be useful for scientists of different disciplines regarding protein engineering and delivery.

\section{Results and Discussions}

\subsection{Primary Dataset and Penetration Prediction of CPPS}

Unique linear CPPs with natural L-conformation amino acids were retrieved from CPPsite 2.0. In general, CPPs with the highest uptake efficiency are preferred for conjugation. Hence, CPP sequences were submitted to the CPPred-RF server to determine the degree of cellular uptake (Table S1). The CPPred-RF webserver is a two-layered prediction engine. The first layer is based on some features, such as physicochemical properties and dipeptide composition. This layer defines if the submitted sequence is cell-penetrating. When the peptide is cell-penetrating, then the second layer of prediction estimates the uptake of the peptide by cells as high or low. In each layer, prediction confidence is reported. Finally, 70 peptides that were predicted to have the highest uptake efficiency with the prediction confidence of above 0.9 were subjected to further analyses (Table 1 ). We have checked whether the 70 top selected CPPs have shown adequate uptake efficiency in experimental studies. The data on previously studied top CPPs, as well as the category of each CPP, are available in Table 2. Levels of uptake for 66 out of 70 CPPs were available from laboratory experiments. As presented in Table 2, all of the 70 selected CPPs have displayed either high or medium uptake efficiency.

Table 2. Experimental data on the uptake efficiency of top 70 CPPs.

\begin{tabular}{|c|c|c|c|}
\hline Category & Names of CPPs & Experimental Uptake Efficiency & References \\
\hline \multirow{17}{*}{$\begin{array}{c}\text { Crot }(27-39) \text { and its } \\
\text { derivatives }\end{array}$} & CyLoP-1 & $\begin{array}{l}\text { High, higher than D-Tat peptide, } \\
\text { penetratin, and D-R8 }\end{array}$ & \multirow{17}{*}{ [29] } \\
\hline & Crot (27-39) & $78 \%$ of CyLoP1 & \\
\hline & Crot (27-39) derivative 1 & $63 \%$ of CyLoP1 & \\
\hline & Crot (27-39) derivative 2 & $66 \%$ of CyLoP1 & \\
\hline & Crot (27-39) derivative 3 & $61 \%$ of CyLoP1 & \\
\hline & Crot (27-39) derivative 4 & $59 \%$ of CyLoP1 & \\
\hline & Crot (27-39) derivative 5 & $47 \%$ of CyLoP1 & \\
\hline & Crot (27-39) derivative 6 & $42 \%$ of CyLoP1 & \\
\hline & Crot (27-39) derivative 7 & $75 \%$ of CyLoP1 & \\
\hline & Crot (27-39) derivative 8 & $39 \%$ of CyLoP1 & \\
\hline & Crot (27-39) derivative 9 & $26 \%$ of CyLoP1 & \\
\hline & Crot (27-39) derivative 10 & $79 \%$ of CyLoP1 & \\
\hline & Crot (27-39) derivative 11 & $58 \%$ of $\mathrm{CyLoP} 1$ & \\
\hline & Crot (27-39) derivative 12 & $29 \%$ of CyLoP1 & \\
\hline & Crot (27-39) derivative 13 & $83 \%$ of CyLoP1 & \\
\hline & Crot (27-39) derivative 14 & $37 \%$ of CyLoP1 & \\
\hline & Crot (27-39) derivative 15 & $46 \%$ of $\mathrm{CyLoP} 1$ & \\
\hline
\end{tabular}


Table 2. Cont.

\begin{tabular}{|c|c|c|c|}
\hline Category & Names of CPPs & Experimental Uptake Efficiency & References \\
\hline \multirow{22}{*}{$\begin{array}{l}\text { Penetratin and its } \\
\text { derivatives }\end{array}$} & Penetratin/pAntp (43-58) & $\begin{array}{l}\text { Lower than polyarginines but higher } \\
\text { than Tat peptide and transportan }\end{array}$ & [30] \\
\hline & pAntp (44-58) & $85 \%$ of pAntp (43-58) & \multirow{19}{*}{ [31] } \\
\hline & pAntp (45-58) & $95 \%$ of pAntp (43-58) & \\
\hline & pAntp (46-58) & $65 \%$ of pAntp (43-58) & \\
\hline & pAntp (47-58) & $50 \%$ of pAntp (43-58) & \\
\hline & pAntp (48-58) & $55 \%$ of pAntp (43-58) & \\
\hline & pAntp (49-58) & $65 \%$ of pAntp (43-58) & \\
\hline & pAntp (50-58) & $60 \%$ of pAntp (43-58) & \\
\hline & pAntp (51-58) & $60 \%$ of pAntp (43-58) & \\
\hline & Ala43 substitution mutant of pAntp (43-58) & $90 \%$ of pAntp (43-58) & \\
\hline & Ala44 substitution mutant of pAntp (43-58) & $65 \%$ of (pAntp) (43-58) & \\
\hline & Ala45 substitution mutant of pAntp (43-58) & $80 \%$ of pAntp (43-58) & \\
\hline & Ala46 substitution mutant of pAntp (43-58) & $50 \%$ of pAntp (43-58) & \\
\hline & Ala47 substitution mutant of pAntp (43-58) & $55 \%$ of pAntp (43-58) & \\
\hline & Ala48 substitution mutant of pAntp (43-58) & $65 \%$ of pAntp (43-58) & \\
\hline & Ala49 substitution mutant of pAntp (43-58) & $90 \%$ of pAntp (43-58) & \\
\hline & Ala50 substitution mutant of pAntp (43-58) & $90 \%$ of pAntp (43-58) & \\
\hline & Ala51 substitution mutant of pAntp (43-58) & $60 \%$ of pAntp (43-58) & \\
\hline & Ala52 substitution mutant of pAntp (43-58) & $45 \%$ of pAntp (43-58) & \\
\hline & Ala54 substitution mutant of pAntp (43-58) & $90 \%$ of pAntp (43-58) & \\
\hline & Met-Arg & Not available & [32] \\
\hline & pAntpHD (Pro50) & $\begin{array}{c}\text { High } \\
\text { Comparable to pAntp (43-58) }\end{array}$ & [33] \\
\hline $\begin{array}{l}\text { CPP derived from } \\
\text { PDX-1 protein }\end{array}$ & PDX-1-PTD & Not available & [34] \\
\hline $\begin{array}{c}\text { Tumor } \\
\text { lineage-homing } \\
\text { CPPs }\end{array}$ & 7 & Not available & [35] \\
\hline \multirow{11}{*}{$\begin{array}{l}\text { Peptide } 14 \text { and its } \\
\text { derivatives }\end{array}$} & No.14 & Higher than Tat peptide & \multirow{11}{*}{ [36] } \\
\hline & No.14-1 & Higher than Tat and peptide No. 14 & \\
\hline & No.14-2 & Higher than Tat peptide & \\
\hline & No.14-7 & Higher than Tat and peptide No. 14 & \\
\hline & No.14-17 & Equal to Peptide No. 14 & \\
\hline & No.14-18 & $\begin{array}{l}\text { Higher than Peptide } 14 \text { and equal to } \\
\text { peptide } 14-1\end{array}$ & \\
\hline & No.14-20 & $\begin{array}{l}\text { Higher than Peptide } 14 \text { and equal to } \\
\text { peptide } 14-1\end{array}$ & \\
\hline & No.14-21 & $\begin{array}{l}\text { Higher than Peptide } 14 \text { and equal to } \\
\text { peptide } 14-1\end{array}$ & \\
\hline & No.14-25 & Equal to peptide 14 & \\
\hline & No.14-30 & $\begin{array}{l}\text { Higher than peptide } 14 \text { and lower } \\
\text { than peptide } 14-1\end{array}$ & \\
\hline & No.14-35 & $\begin{array}{l}\text { Higher than Peptide } 14 \text { and equal to } \\
\text { peptide } 14-1\end{array}$ & \\
\hline
\end{tabular}


Table 2. Cont.

\begin{tabular}{|c|c|c|c|}
\hline Category & Names of CPPs & Experimental Uptake Efficiency & References \\
\hline \multirow{5}{*}{$\begin{array}{l}\text { Cell-penetrating } \\
\text { penta peptides } \\
\text { (CPP5s) }\end{array}$} & Bip1 & $\begin{array}{c}\text { High } \\
\text { About } 97 \% \text { of KLPVM }\end{array}$ & \multirow{5}{*}{ [37] } \\
\hline & Bip2 & About $61 \%$ of KLPVM) & \\
\hline & Bip6 & About $71 \%$ of KLPVM & \\
\hline & Bip15 & Not available & \\
\hline & Bip16 & About 70\% KLPVM & \\
\hline \multirow{3}{*}{$\begin{array}{l}\text { pVEC (CPP derived } \\
\text { from murine } \\
\text { vascular endothelial } \\
\text { cadherin) }\end{array}$} & pVEC mutant 1 & Comparable to $\mathrm{pVEC}$ & \multirow{3}{*}{ [38] } \\
\hline & pVEC mutant 2 & Higher than pVEC & \\
\hline & pVEC mutant 3 & Comparable to pVEC & \\
\hline \multirow{4}{*}{$\begin{array}{l}\text { Tat peptide and its } \\
\text { derivatives }\end{array}$} & Tat $(48-60)$ & $\begin{array}{c}\text { High } \\
\text { Lower than polyarginine and } \\
\text { penetratin but equal to transportan }\end{array}$ & {$[30,39]$} \\
\hline & $\operatorname{Rev}(34-50)$ & $\begin{array}{c}\text { High } \\
\text { Comparable to Tat }(48-60)\end{array}$ & [40] \\
\hline & HIV-1 Rev (34-50) & 2.5-6.6 times more than Tat (48-60) & [41] \\
\hline & Retro - Tat (57-49) & $\begin{array}{c}\text { High } \\
\text { Compared to Tat (49-57) }\end{array}$ & [42] \\
\hline \multirow{2}{*}{ Polyarginines } & R6 & Lower than R9 & \multirow{2}{*}{ [42] } \\
\hline & R9 & High & \\
\hline $\begin{array}{c}\text { Transportan peptide } \\
\text { derivative }\end{array}$ & Transportan 10 (TP10) & High & [43] \\
\hline \multirow{2}{*}{$\begin{array}{l}\text { CPPs derived from } \\
\text { tumor suppressor } \\
\text { protein p14ARF }\end{array}$} & $\operatorname{ARF}(1-22)$ & $\begin{array}{c}\text { High } \\
\text { Comparable to TP10 }\end{array}$ & [43] \\
\hline & M918 & Higher than Penetratin & [44] \\
\hline $\begin{array}{c}\alpha \text {-helical } \\
\text { amphipathic CPPs }\end{array}$ & II & High & [45] \\
\hline
\end{tabular}

There is some evidence available that the secondary structure of an amphipathic CPP is correlated to its uptake efficiency [46-48]. Therefore, secondary structures of the top 70 CPPs after conjugation with CPG2, for both $\mathrm{N}$ - and C-terminal positions were recorded. When a CPP folds into an $\alpha$-helix or $\beta$-sheet it potentially penetrates the cells more efficiently. Therefore, the percentage of amino acids that are able to form helices and sheets was calculated for the CPP fragment within each conjugate (Table 3). According to the acquired results, peptides 3, 4, 6, 14, 56, and 62 in N-terminal and peptides $2,14,43,52,56$, and 58 in C-terminal conjugation have more than $85 \%$ amino acids with helix and sheet configuration. It should be noted that compared with the C-terminal conjugation of CPPs, $\mathrm{N}$-terminal homologs resulted in a significantly higher percentage of amino acids with the helix and sheet configuration (Figure 1).

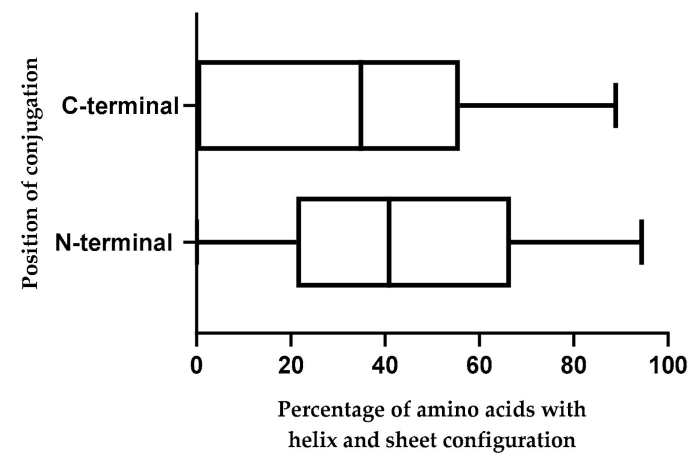

Figure 1. The percentage of distribution of amino acids with helix and sheet configuration in the $\mathrm{N}$-terminal (CPP-CPG2) and C-terminal (CPG2-CPP) conjugates. 
Table 3. Top 70 CPPs' secondary structure prediction after conjugation with CPG2.

\begin{tabular}{|c|c|c|c|c|c|}
\hline \multirow[b]{2}{*}{ Peptide Number } & \multirow[b]{2}{*}{ CPPs' Names } & \multicolumn{2}{|c|}{ N-Terminal Conjugation with CPG2 } & \multicolumn{2}{|c|}{ C-Terminal Conjugation with CPG2 } \\
\hline & & $\begin{array}{l}\text { Secondary Structure after } \\
\text { Conjugation with CPG2 } \\
\text { (C: coil, S: Sheet, H: Helix) }\end{array}$ & $\begin{array}{l}\text { Percentage of Amino } \\
\text { Acids with Helix and } \\
\text { Sheet Configuration }\end{array}$ & $\begin{array}{l}\text { Secondary Structure after } \\
\text { Conjugation with CPG2 } \\
\text { (C: coil, S: sheet, H: helix) }\end{array}$ & $\begin{array}{l}\text { Percentage of Amino } \\
\text { Acids with Helix and } \\
\text { Sheet Configuration }\end{array}$ \\
\hline 1 & Transportan 10 (TP10) & CCSSSSSCHHHHCCCCCHHHC & 57.1 & ССССССССССНHНHНHНHНСС & 42.9 \\
\hline 2 & Ala43 substitution mutant of pAntp (43-58) & ССНHНHНHНСССССHН & 56.2 & HHНHНHНHНHНHНHCC & 87.5 \\
\hline 3 & Crot (27-39) derivative 1 & CSSSSSHHHH & 90.0 & CCCSSSSCCC & 40.0 \\
\hline 4 & Crot (27-39) derivative 2 & CSSSSSSHHH & 90.0 & CCCSSSSCCC & 40.0 \\
\hline 5 & Crot (27-39) derivative 3 & CSSSSSSCHH & 80.0 & CCHHHSSCCC & 50.0 \\
\hline 6 & CyLoP-1 & CSSSHHHHHH & 90.0 & СССССССССС & 0.0 \\
\hline 7 & Crot (27-39) derivative 4 & СССССССССH & 9.1 & ССССССССССС & 0.0 \\
\hline 8 & Crot (27-39) derivative 5 & CCSSSSHHHHH & 81.8 & СННННННСССС & 54.5 \\
\hline 9 & pAntp (49-58) & ССССНHНHНH & 60.0 & СССССССССС & 0.0 \\
\hline 10 & Tat $(48-60)$ & ССССССССССССС & 0.0 & ССССССССССССС & 0.0 \\
\hline 11 & pAntp (45-58) & CCSSSCCCCCCCHH & 35.7 & СССССССССССССС & 0.0 \\
\hline 12 & Bip15 & CCCСC & 0.0 & CCCCC & 0.0 \\
\hline 13 & pAntp (47-58) & ССССССССССHH & 16.7 & СССССССССССС & 0.0 \\
\hline 14 & II & CHНHНHНHНHНHНHНHНH & 94.4 & НHНHНHНHНHНHНHНHCC & 88.9 \\
\hline 15 & Crot (27-39) derivative 6 & СССССССССС & 0.0 & СССССССССС & 0.0 \\
\hline 16 & Crot (27-39) derivative 7 & ССССССССССССH & 7.1 & СCHНHHHHHCCCCC & 50.0 \\
\hline 17 & Crot (27-39) derivative 8 & CCSSSSSCHHH & 27.3 & ССССССССССС & 0.0 \\
\hline 18 & Crot (27-39) derivative 9 & CCCSSSSHHHHH & 41.7 & СССССССНHССС & 16.7 \\
\hline 19 & pAntp (46-58) & СCCССCССCCCHH & 15.4 & СССССНHНHНHCC & 46.2 \\
\hline 20 & 7 & CCCSSSCCCCCCCCH & 26.7 & ССССССССССССССС & 0.0 \\
\hline 21 & No.14-2 & СНHНHНHНHНHНCCC & 73.3 & HНHCCСCHНHНCCCC & 46.7 \\
\hline 22 & No.14 & CCSSSSSCCCCCCHH & 53.3 & ССССССССССССССС & 0.0 \\
\hline 23 & No.14-7 & ССНННННССССНHНH & 60.0 & ССССССССССССССС & 0.0 \\
\hline
\end{tabular}


Table 3. Cont.

\begin{tabular}{|c|c|c|c|c|c|}
\hline \multirow[b]{2}{*}{ Peptide Number } & \multirow[b]{2}{*}{ CPPs' Names } & \multicolumn{2}{|c|}{ N-Terminal Conjugation with CPG2 } & \multicolumn{2}{|c|}{ C-Terminal Conjugation with CPG2 } \\
\hline & & $\begin{array}{l}\text { Secondary Structure after } \\
\text { Conjugation with CPG2 } \\
\text { (C: coil, S: Sheet, H: Helix) }\end{array}$ & $\begin{array}{l}\text { Percentage of Amino } \\
\text { Acids with Helix and } \\
\text { Sheet Configuration }\end{array}$ & $\begin{array}{l}\text { Secondary Structure after } \\
\text { Conjugation with CPG2 } \\
\text { (C: coil, S: sheet, H: helix) }\end{array}$ & $\begin{array}{l}\text { Percentage of Amino } \\
\text { Acids with Helix and } \\
\text { Sheet Configuration }\end{array}$ \\
\hline 24 & Crot (27-39) & CCCSSSSSHHHHH & 76.9 & СССССНHНHНССС & 38.5 \\
\hline 25 & Crot (27-39) derivative 10 & CCCCSSHHHHHH & 66.7 & ССССССССССС & 0.0 \\
\hline 26 & Crot (27-39) derivative 11 & CCCCCCSSCCCHH & 30.8 & ССССССССССССС & 0.0 \\
\hline 27 & Crot (27-39) derivative 12 & CCCSSSSHHHHHH & 76.9 & ССССНHНHНHCCC & 46.2 \\
\hline 28 & pVEC mutant 1 & СНHНHНHНHНССССССCH & 55.5 & ССНHНHНHНHНHНHCCCC & 66.7 \\
\hline 29 & pVEC mutant 2 & CCSSSHHHHНCCCCCCCC & 44.4 & НHНHНННННННССССССС & 61.1 \\
\hline 30 & pVEC mutant 3 & CSSSHHHHHHHCCCCCCH & 61.1 & ССНHНHНHНHНHНССССС & 61.1 \\
\hline 31 & Crot (27-39) derivative 13 & CCCSSSSHHHHH & 75.0 & ССССНHНHНССС & 41.7 \\
\hline 32 & $\operatorname{ARF}(1-22)$ & СССНHНHНHНHНHНHСССССС & 54.5 & НHНHНHНHНHНССССССССССС & 50.0 \\
\hline 33 & M918 & CCSSHНHНHНHНННСССССССС & 54.5 & ССННННННННСССССССССССС & 36.4 \\
\hline 34 & pAntp (51-58) & CCCCCCHH & 25.0 & СССССССС & 0.0 \\
\hline 35 & pAntp (44-58) & СССНHНHССССССНH & 40.0 & НHНHНHНHНСССССС & 60.0 \\
\hline 36 & pAntp (50-58) & ССССССНH & 22.2 & ССССССССС & 0.0 \\
\hline 37 & Ala44 substitution mutant of pAntp (43-58) & СCCCHHHCCCCCCCHH & 31.2 & НHНHНHНHCCHНHCCC & 68.8 \\
\hline 38 & PDX -1-PTD & СССНHНHСССССССНH & 37.5 & НННННННННННССССС & 68.8 \\
\hline 39 & No.14-25 & CSSSSSCCCHНHНHН & 73.3 & СННСССССССССССС & 13.3 \\
\hline 40 & No.14-17 & CSSSSCCCCCCHHHH & 53.3 & НHНHССССССССССС & 26.7 \\
\hline 41 & No.14-18 & CCSSSSSCCCCCCCC & 33.3 & НННННННСССССССС & 46.7 \\
\hline 42 & No.14-20 & ССССССССССССС & 6.7 & ССССССССССССССС & 0.0 \\
\hline 43 & No.14-21 & CCSSSSSSCCCHHHH & 66.7 & НННННННННННННСС & 86.7 \\
\hline 44 & No.14-1135 & CCSSSSSCCCCСCCC & 33.3 & СССССССССССССС & 0.0 \\
\hline 45 & No.14-1 & CCCSSSCCCCCCCHH & 33.3 & ССССССССССССССС & 0.0 \\
\hline 46 & 30 & CCCSSSCCCHHНHCC & 46.7 & ССССССССССССССС & 0.0 \\
\hline
\end{tabular}


Table 3. Cont

\begin{tabular}{|c|c|c|c|c|c|}
\hline \multirow[b]{2}{*}{ Peptide Number } & \multirow[b]{2}{*}{ CPPs' Names } & \multicolumn{2}{|c|}{ N-Terminal Conjugation with CPG2 } & \multicolumn{2}{|c|}{ C-Terminal Conjugation with CPG2 } \\
\hline & & $\begin{array}{l}\text { Secondary Structure after } \\
\text { Conjugation with CPG2 } \\
\text { (C: coil, S: Sheet, H: Helix) }\end{array}$ & $\begin{array}{l}\text { Percentage of Amino } \\
\text { Acids with Helix and } \\
\text { Sheet Configuration }\end{array}$ & $\begin{array}{l}\text { Secondary Structure after } \\
\text { Conjugation with CPG2 } \\
\text { (C: coil, S: sheet, H: helix) }\end{array}$ & $\begin{array}{l}\text { Percentage of Amino } \\
\text { Acids with Helix and } \\
\text { Sheet Configuration }\end{array}$ \\
\hline 47 & Ala45 substitution mutant of pAntp (43-58) & CCCSSSSCCCCCCCHH & 37.5 & НННННННННННННССС & 81.3 \\
\hline 48 & Ala46 substitution mutant of pAntp (43-58) & CCSSSSSCCCCCCCHH & 43.7 & HHHHHHHCCCHHHHCC & 68.8 \\
\hline 49 & Ala47 substitution mutant of pAntp (43-58) & ССНHНСССССССССHH & 31.2 & НHНHНHНHНHСССССС & 62.5 \\
\hline 50 & Ala48 substitution mutant of pAntp (43-58) & ССНHНHНHНССССССС & 43.7 & ССССНHНСHНHНHСCC & 50.0 \\
\hline 51 & Ala49 substitution mutant of pAntp (43-58) & CCCSSCCCCCCCCCHH & 25 & HНССНHНHСССНHCCC & 50.0 \\
\hline 52 & Ala50 substitution mutant of pAntp (43-58) & CCSSSSSCCCCCCCHH & 43.7 & НHНHННННННННСССС & 87.5 \\
\hline 53 & pAntpHD (Pro50) & ССССССССССССССHH & 12.5 & HHHHHHCCCCHHHCCC & 68.8 \\
\hline 54 & Ala51 substitution mutant of pAntp (43-58) & CCCSSSSCCCCCCCCH & 31.2 & ССССССНHНHНHНHCC & 50.0 \\
\hline 55 & Ala52 substitution mutant of pAntp(43-58) & ССНННННННННННССС & 68.7 & СССССНHНССНHНCСC & 37.5 \\
\hline 56 & Met-Arg & ССНННННННННННННН & 87.5 & ННННННННННННННСС & 87.5 \\
\hline 57 & Ala54 substitution mutant of pAntp(43-58) & CSSSHHНССCССCCHH & 50.0 & НHНHНHНHССНHНHCC & 75.0 \\
\hline 58 & Penetratin & CCSSSSSCCCCCCCCH & 37.5 & НHНHНHНHНHНHНHCC & 87.5 \\
\hline 59 & Retro - Tat (57-49) & ССССССССС & 0.0 & ССССССССС & 0.0 \\
\hline 60 & R6 & ССНHНH & 66.7 & СССССС & 0.0 \\
\hline 61 & R9 & ССССССССС & 0.0 & ССССНHСCC & 22.2 \\
\hline 62 & Crot (27-39) derivative 14 & CSSHHНHНH & 88.9 & CCCSSSCCC & 33.3 \\
\hline 63 & Crot (27-39) derivative 15 & CCSSSHHHHH & 80.0 & СССССССССС & 0.0 \\
\hline 64 & $\operatorname{Rev}(34-50)$ & ССССССССССССССССС & 0.0 & ССССССССССССССССС & 0.0 \\
\hline 65 & HIV-1 Rev (34-50) & СССССССССНHНHНHНССС & 36.8 & ССССССССССССССССССС & 0.0 \\
\hline 66 & Bip6 & CCCCC & 0.0 & CCCCC & 0.0 \\
\hline 67 & Bip1 & CCCCC & 0.0 & CCCCC & 0.0 \\
\hline 68 & Bip2 & CCCCC & 0.0 & CCCCC & 0.0 \\
\hline 69 & Bip16 & CCCCC & 0.0 & CCCCC & 0.0 \\
\hline 70 & pAntp (48-58) & ССССССССCHН & 18.2 & ССССССССССС & 0.0 \\
\hline
\end{tabular}




\section{2. $m R N A$ Secondary Structure Prediction of cpp-cpg2/cpg2-cpp Conjugates}

The stability of the mRNA structure affects the expression level of proteins. A more positive $\Delta G$ value of the mRNA secondary structure in the translation initiation region correlates with a higher probability of the translation of mRNA into protein [49]. The obtained $\Delta G$ values from the mfold server indicated that $74 \%$ of the $N$-terminal conjugates had higher $\Delta G$ values compared with the unconjugated CPG2. N-terminal conjugates from peptides 10, 18, 31, 36, and 61 displayed the highest $\Delta G$ values. Besides $\Delta G$, the level of exposure of the AUG start codon in the mRNA secondary structure has a regulatory effect on the rate of protein translation in E. coli. If the start codon locates on a loop, higher exposure to the ribosomal subunit occurs and results in a higher level of translation compared with a start codon on the stem [50]. In this study, in 50\% of the N-terminal conjugates, the start codon was located on a loop and in the rest of the conjugates, as well as CPG2 itself, the starting codon was on the stem. Secondary structures of two conjugates and CPG2 are shown in Figure 2.

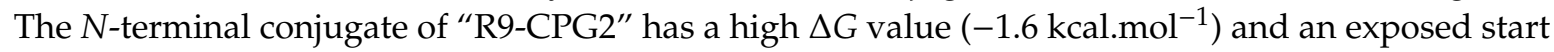
codon, while "Transportan 10-CPG2" $N$-terminal conjugate displays a low $\Delta G$ value $\left(-13.2 \mathrm{kcal}^{\left.-\mathrm{mol}^{-1}\right)}\right.$ and its start codon is not exposed. $\Delta G$ values and position of the start codon for all of the conjugates are available in Table S2. It should be noted that all the seventy C-terminal conjugates have the same initiation translation region as the control unconjugated CPG2.
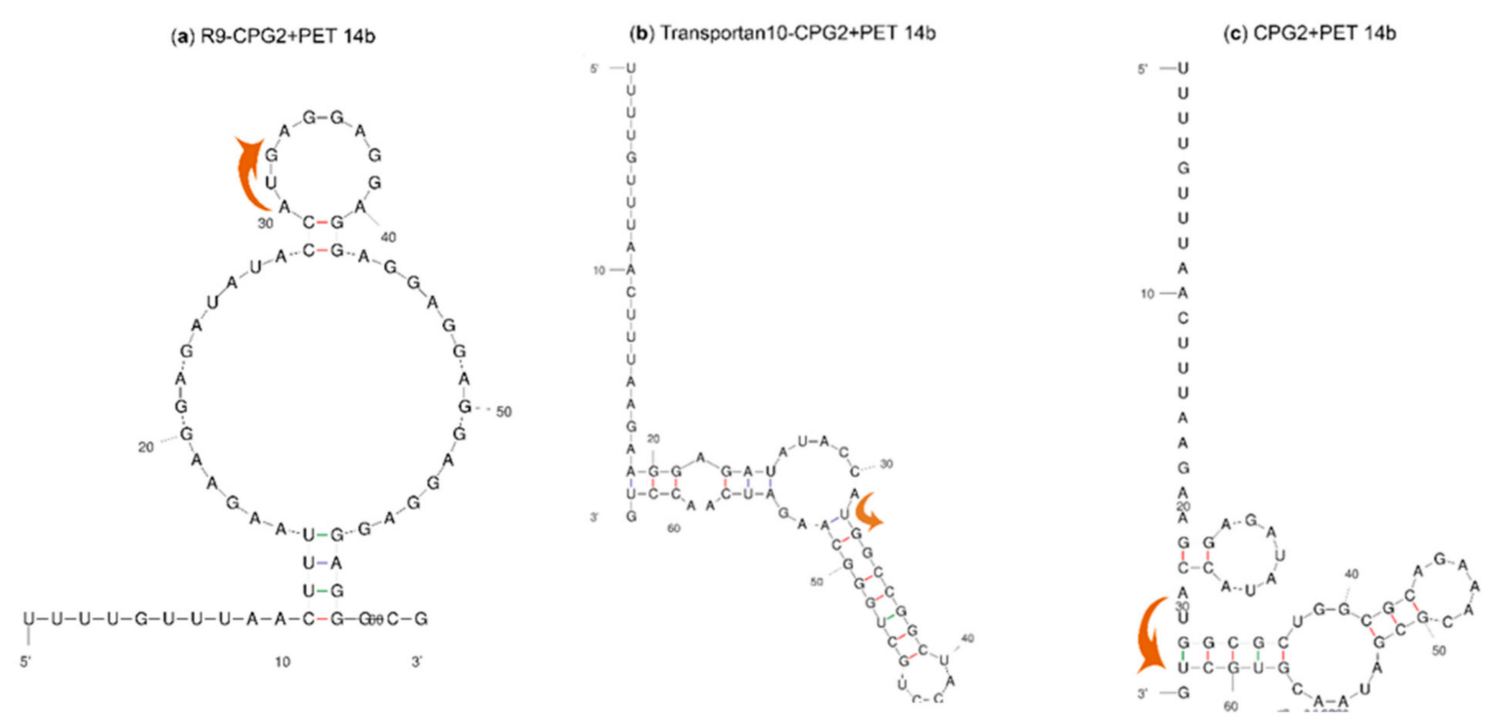

Figure 2. mRNA initiation translation region secondary structures and location of the start codon (indicated by arrows) for two conjugates and CPG2. (a) "R9-CPG2 + PET 14b" has a higher $\triangle G$ value compared with CPG2 and the start codon is exposed (b) "Transportan 10-CPG2 + PET 14b" has a lower $\triangle G$ value compared with CPG2 and the start codon is not exposed. (c) Control CPG2 + PET 14b: start codon is not exposed.

\subsection{Physiochemical Properties of CPPs and CPP-CPG2/CPG2-CPP Conjugates}

Various physiochemical properties were calculated for CPG2 and the top 70 CPPs both alone (Table S3) and in conjugation to CPG2 at the $N$-terminal (Table 4) and C-terminal (Table S4) positions via ProtParam tool. Top 70 CPPs' lengths were between 5-22 amino acids. All the top 70 CPPs except number 69 have basic $\mathrm{pI}$ (Table S3), indicating an overall positive charge in the blood $\mathrm{pH}$ (7.4). The $\mathrm{pI}$ of unconjugated CPG2 was calculated to be 6.22. Only fusion proteins resulting from peptides 12,66 , 67,68 , and 69 had an acidic pI due to the anionic nature of CPPs (Table 4). The rest of the conjugates would have an overall positive charge at $\mathrm{pH}=7.4$. None of the conjugates had a $\mathrm{pI}$ near 7.4, indicating a low risk of protein aggregation due to $\mathrm{pI}$ after administration. 
Table 4. Physiochemical properties of CPP-CPG2 N-terminal conjugates.

\begin{tabular}{|c|c|c|c|c|c|c|c|}
\hline Peptide Number & Name of the Conjugate & Number of Amino Acids & Mw (Da) & $\mathrm{pI}$ & Instability Index & Aliphatic Index & GRAVY \\
\hline 1 & Transportan 10 (TP10)-CPG2 & 414 & 43860.19 & 8.37 & 23.99 & 97.20 & -0.116 \\
\hline 2 & $\begin{array}{l}\text { Ala43 substitution mutant of pAntp } \\
\text { (43-58)-CPG2 }\end{array}$ & 409 & 43839.07 & 8.82 & 25.71 & 91.69 & -0.218 \\
\hline 3 & Crot (27-39) derevative 1-CPG2 & 403 & 42996.11 & 8.48 & 24.58 & 90.87 & -0.187 \\
\hline 4 & Crot (27-39) derevative 2-CPG2 & 403 & 43035.15 & 8.48 & 26.37 & 90.87 & -0.196 \\
\hline 5 & Crot (27-39) derevative 3-CPG2 & 403 & 43035.15 & 8.48 & 26.00 & 90.87 & -0.196 \\
\hline 6 & CyLoP-1-CPG2 & 403 & 43074.18 & 8.48 & 27.79 & 90.87 & -0.205 \\
\hline 7 & Crot (27-39) derevative 4-CPG2 & 404 & 43131.24 & 8.48 & 27.75 & 90.64 & -0.206 \\
\hline 8 & Crot (27-39) derevative 5-CPG2 & 404 & 43189.27 & 8.21 & 27.75 & 90.64 & -0.214 \\
\hline 9 & pAntp (49-58)-CPG2 & 403 & 43099.16 & 8.65 & 26.37 & 90.87 & -0.228 \\
\hline 10 & Tat (48-60)-CPG2 & 406 & 43396.46 & 9.08 & 31.77 & 90.20 & -0.279 \\
\hline 11 & pAntp (45-58)-CPG2 & 407 & 43639.86 & 8.82 & 25.79 & 91.89 & -0.215 \\
\hline 12 & Bip15-CPG2 & 398 & 42278.25 & 6.56 & 24.66 & 93.97 & -0.159 \\
\hline 13 & pAntp (47-58)-CPG2 & 405 & 43398.53 & 8.65 & 26.29 & 91.38 & -0.218 \\
\hline 14 & II-CPG2 & 411 & 43554.90 & 8.64 & 23.83 & 97.20 & -0.121 \\
\hline 15 & Crot (27-39) derevative 6-CPG2 & 403 & 43074.18 & 8.48 & 26.37 & 90.87 & -0.205 \\
\hline 16 & Crot (27-39) derevative 7-CPG2 & 407 & 43419.60 & 8.61 & 27.62 & 89.98 & -0.209 \\
\hline 17 & Crot (27-39) derevative 8-CPG2 & 404 & 43202.36 & 8.66 & 27.75 & 90.64 & -0.215 \\
\hline 18 & Crot (27-39) derevative 9-CPG2 & 405 & 43317.45 & 8.47 & 27.70 & 90.42 & -0.223 \\
\hline 19 & pAntp (46-58)-CPG2 & 406 & 43526.70 & 8.82 & 26.04 & 91.16 & -0.227 \\
\hline 20 & 7-CPG2 & 408 & 43701.80 & 8.39 & 28.82 & 90.71 & -0.215 \\
\hline 21 & No.14-2-CPG2 & 408 & 43652.73 & 8.38 & 27.74 & 90.96 & -0.208 \\
\hline 22 & No.14-CPG2 & 408 & 43678.77 & 8.38 & 28.82 & 90.71 & -0.216 \\
\hline 23 & No.14-7-CPG2 & 408 & 43763.88 & 8.38 & 28.38 & 90.71 & -0.216 \\
\hline 24 & Crot (27-39)-CPG2 & 406 & 43448.64 & 8.47 & 28.46 & 90.20 & -0.217 \\
\hline
\end{tabular}


Table 4. Cont.

\begin{tabular}{|c|c|c|c|c|c|c|c|}
\hline Peptide Number & Name of the Conjugate & Number of Amino Acids & Mw (Da) & pI & Instability Index & Aliphatic Index & GRAVY \\
\hline 25 & Crot (27-39) derevative 10-CPG2 & 405 & 43345.50 & 8.53 & 28.51 & 90.42 & -0.224 \\
\hline 26 & Crot (27-39) derevative 11-CPG2 & 406 & 43432.58 & 8.53 & 28.46 & 90.20 & -0.226 \\
\hline 27 & Crot (27-39) derevative 12-CPG2 & 406 & 43432.58 & 8.53 & 29.27 & 90.20 & -0.226 \\
\hline 28 & pVEC mutant 1-CPG2 & 411 & 43802.04 & 8.66 & 25.76 & 95.52 & -0.169 \\
\hline 29 & pVEC mutant 2-CPG2 & 411 & 43802.04 & 8.66 & 27.15 & 95.52 & -0.169 \\
\hline 30 & pVEC mutant 3-CPG2 & 411 & 43830.05 & 8.67 & 27.97 & 95.52 & -0.171 \\
\hline 31 & Crot (27-39) derevative 13-CPG2 & 405 & 43320.46 & 8.17 & 27.70 & 90.42 & -0.208 \\
\hline 32 & ARF(1-22)-CPG2 & 415 & 44329.74 & 8.93 & 28.88 & 94.10 & -0.158 \\
\hline 33 & M918-CPG2 & 415 & 44329.74 & 8.93 & 28.88 & 94.10 & -0.158 \\
\hline 34 & pAntp (51-58)-CPG2 & 401 & 42823.85 & 8.65 & 26.45 & 91.32 & -0.227 \\
\hline 35 & pAntp (44-58)-CPG2 & 408 & 43767.99 & 8.82 & 25.75 & 91.67 & -0.223 \\
\hline 36 & pAntp (50-58)-CPG2 & 402 & 42951.98 & 8.65 & 26.41 & 91.09 & -0.235 \\
\hline 37 & $\begin{array}{l}\text { Ala44 substitution mutant of pAntp } \\
\qquad(43-58)-C P G 2\end{array}$ & 409 & 43867.13 & 8.95 & 25.71 & 91.69 & -0.221 \\
\hline 38 & PDX -1-PTD-CPG2 & 409 & 43933.19 & 8.95 & 27.26 & 91.44 & -0.233 \\
\hline 39 & No.14-25-CPG2 & 408 & 43628.71 & 8.39 & 27.26 & 90.71 & -0.199 \\
\hline 40 & No.14-17-CPG2 & 408 & 43614.68 & 8.40 & 28.66 & 90.96 & -0.210 \\
\hline 41 & No.14-18-CPG2 & 408 & 43690.78 & 8.39 & 29.00 & 90.96 & -0.211 \\
\hline 42 & No.14-20-CPG2 & 408 & 43676.75 & 8.39 & 29.50 & 90.96 & -0.211 \\
\hline 43 & No.14-21-CPG2 & 408 & 43676.75 & 8.39 & 29.02 & 90.96 & -0.211 \\
\hline 44 & No.14-35-CPG2 & 408 & 43720.81 & 8.39 & 30.02 & 90.96 & -0.212 \\
\hline 45 & No.14-1-CPG2 & 408 & 43706.78 & 8.39 & 29.02 & 90.71 & -0.217 \\
\hline 46 & 30-CPG2 & 408 & 43660.71 & 8.37 & 27.65 & 90.71 & -0.219 \\
\hline 47 & $\begin{array}{l}\text { Ala45 substitution mutant of pAntp } \\
\text { (43-58)-CPG2 }\end{array}$ & 409 & 43882.10 & 8.95 & 26.39 & 90.73 & -0.240 \\
\hline
\end{tabular}


Table 4. Cont

\begin{tabular}{|c|c|c|c|c|c|c|c|}
\hline Peptide Number & Name of the Conjugate & Number of Amino Acids & Mw (Da) & pI & Instability Index & Aliphatic Index & GRAVY \\
\hline 48 & $\begin{array}{l}\text { Ala46 substitution mutant of pAntp } \\
\text { (43-58)-CPG2 }\end{array}$ & 409 & 43867.09 & 8.83 & 26.60 & 91.69 & -0.220 \\
\hline 49 & $\begin{array}{l}\text { Ala47 substitution mutant of pAntp } \\
\qquad(43-58)-C P G 2\end{array}$ & 409 & 43882.10 & 8.95 & 26.39 & 90.73 & -0.240 \\
\hline 50 & $\begin{array}{l}\text { Ala48 substitution mutant of pAntp } \\
\text { (43-58)-CPG2 }\end{array}$ & 409 & 43809.00 & 8.95 & 26.19 & 91.69 & -0.227 \\
\hline 51 & $\begin{array}{l}\text { Ala49 substitution mutant of pAntp } \\
\text { (43-58)-CPG2 }\end{array}$ & 409 & 43848.08 & 8.95 & 25.82 & 91.69 & -0.236 \\
\hline 52 & $\begin{array}{l}\text { Ala50 substitution mutant of pAntp } \\
\text { (43-58)-CPG2 }\end{array}$ & 409 & 43867.13 & 8.95 & 26.19 & 91.69 & -0.221 \\
\hline 53 & pAntpHD (Pro50)-CPG2 & 409 & 43893.17 & 8.95 & 26.66 & 91.44 & -0.229 \\
\hline 54 & $\begin{array}{l}\text { Ala51 substitution mutant of pAntp } \\
\text { (43-58)-CPG2 }\end{array}$ & 409 & 43881.16 & 8.95 & 26.19 & 91.69 & -0.221 \\
\hline 55 & $\begin{array}{l}\text { Ala52 substitution mutant of pAntp } \\
(43-58)-C P G 2\end{array}$ & 409 & 43839.07 & 8.82 & 24.78 & 91.69 & -0.218 \\
\hline 56 & Met-Arg-CPG2 & 409 & 43924.18 & 8.95 & 26.00 & 91.44 & -0.233 \\
\hline 57 & $\begin{array}{l}\text { Ala54 substitution mutant of pAntp } \\
\text { (43-58)-CPG2 }\end{array}$ & 409 & 43864.07 & 8.95 & 26.19 & 91.69 & -0.234 \\
\hline 58 & Penetratin-CPG2 & 409 & 43924.18 & 8.95 & 26.19 & 91.44 & -0.233 \\
\hline 59 & Retro - Tat (57-49)-CPG2 & 402 & 43017.05 & 9.08 & 30.55 & 91.09 & -0.264 \\
\hline 60 & R6-CPG2 & 399 & 42632.57 & 8.86 & 32.28 & 91.78 & -0.238 \\
\hline 61 & R9-CPG2 & 402 & 43101.13 & 9.19 & 36.38 & 91.09 & -0.269 \\
\hline 62 & Crot (27-39) derevative 14-CPG2 & 402 & 42971.04 & 8.53 & 27.84 & 91.09 & -0.212 \\
\hline 63 & Crot (27-39) derevative 15-CPG2 & 403 & 43058.12 & 8.52 & 28.27 & 90.87 & -0.214 \\
\hline 64 & $\operatorname{Rev}(34-50)-C P G 2$ & 410 & 44115.2 & 9.18 & 32.92 & 89.56 & -0.309 \\
\hline 65 & HIV-1 Rev (34-50)-CPG2 & 412 & 44275.39 & 9.13 & 32.60 & 89.13 & -0.302 \\
\hline
\end{tabular}


Table 4. Cont.

\begin{tabular}{|c|c|c|c|c|c|c|c|}
\hline Peptide Number & Name of the Conjugate & Number of Amino Acids & Mw (Da) & pI & Instability Index & Aliphatic Index & GRAVY \\
\hline 66 & Bip6-CPG2 & 398 & 42204.11 & 6.55 & 25.89 & 93.97 & -0.160 \\
\hline 67 & Bip1-CPG2 & 398 & 42264.22 & 6.55 & 25.22 & 93.72 & -0.159 \\
\hline 68 & Bip2-CPG2 & 398 & 42234.13 & 6.55 & 25.41 & 93.72 & -0.166 \\
\hline 69 & Bip16-CPG2 & 398 & 42234.09 & 6.22 & 26.44 & 93.72 & -0.165 \\
\hline \multirow[t]{2}{*}{70} & pAntp (48-58)-CPG2 & 404 & 43285.37 & 8.65 & 26.33 & 90.64 & -0.229 \\
\hline & CPG2 & 393 & 41695.44 & 6.22 & 25.33 & 93.18 & -0.173 \\
\hline
\end{tabular}


The instability index for all the conjugates is less than 40 , indicating that the conjugates are probably stable in the test tube. However, only conjugates resulting from peptides $1,3,12,14,55$, and 67 do not have elevated instability index compared with the unconjugated CPG2. GRAVY value for all the conjugates is negative, which means all of them are hydrophilic. Compared with CPG2, the GRAVY for conjugates resulting from peptides 1, 12, 14, 28, 29, 30, 32, 33, 66, 67, 68, and 69 showed higher values which could result in higher hydrophobicity. This might, in turn, leads to an increased chance of aggregation. All the conjugates composed of "CPP5s" and "pVEC mutants" showed an increase in GRAVY value compared with CPG2. There was no significant difference between the physiochemical properties of the $\mathrm{N}$ - and C-terminal conjugates.

\subsection{The Solubility of CPP-CPG2 and CPG2-CPP Conjugates}

The solubility of the top 70 CPPs conjugated to CPG2, regarding both $\mathrm{N}$ - and C-terminal conjugations were predicted using the ccSOL server (Table 5). The solubility of proteins is a crucial factor for the production, formulation, and delivery of protein-based therapeutics. Solubility is influenced by extrinsic and intrinsic factors. By optimizing extrinsic factors such as $\mathrm{pH}$, ionic strength, the temperature of the solvent, and in the presence of various additives, protein solubility can be increased. The intrinsic factors are mostly related to the amino acids on the proteins' surface [51]. CPPs have been used to increase the aqueous solubility of their cargo. For instance, the conjugation of taxol to CPPs resulted in the improvement of taxol's poor solubility [52,53]. CcSol predicts the percentage of protein solubility. On average, conjugates from "CCP5s" and some "Crot derivatives" displayed an overall higher solubility score. Higher solubility of the "CCP5" family might be due to the increased negative charge on the protein's surface associated with the anionic nature of these CPPs [51]. However, due to differences between results from different solubility prediction servers, further experimental validations are required to reach a definite conclusion. The $\mathrm{N}$ - and C-terminal CPP-CPG2 and CPG2-CPP conjugates had an average solubility of $79.69 \%$ and $79.44 \%$, respectively. Therefore, the position of a conjugation had no significant effect on the solubility.

Table 5. Solubility prediction of CPG2 and top 70 CPPs conjugated to both $N$ - and C-terminus of CPG2 using the ccsol server.

\begin{tabular}{|c|c|c|c|}
\hline Peptide Number & Name of the Conjugate & $\begin{array}{c}\text { The Solubility } \\
\text { Percentage of } \\
\text { CPP-CPG2 N-Terminal } \\
\text { Conjugates }\end{array}$ & $\begin{array}{c}\text { The Solubility } \\
\text { Percentage of } \\
\text { CPG2-CPP C-Terminal } \\
\text { Conjugates }\end{array}$ \\
\hline 1 & Transportan 10 (TP10)-CPG2 & $86 \%$ & $86 \%$ \\
\hline 2 & $\begin{array}{l}\text { Ala43 substitution mutant of } \\
\text { pAntp (43-58)-CPG2 }\end{array}$ & $79 \%$ & $79 \%$ \\
\hline 3 & Crot (27-39) derevative 1-CPG2 & $87 \%$ & $84 \%$ \\
\hline 4 & Crot (27-39) derevative 2-CPG2 & $86 \%$ & $83 \%$ \\
\hline 5 & Crot (27-39) derevative 3-CPG2 & $86 \%$ & $83 \%$ \\
\hline 6 & CyLoP-1-CPG2 & $85 \%$ & $82 \%$ \\
\hline 7 & Crot (27-39) derevative 4-CPG2 & $86 \%$ & $82 \%$ \\
\hline 8 & Crot (27-39) derevative 5-CPG2 & $85 \%$ & $83 \%$ \\
\hline 9 & pAntp (49-58)-CPG2 & $82 \%$ & $81 \%$ \\
\hline 10 & Tat (48-60)-CPG2 & $79 \%$ & $82 \%$ \\
\hline 11 & pAntp (45-58)-CPG2 & $80 \%$ & $79 \%$ \\
\hline 12 & Bip15-CPG2 & $84 \%$ & $84 \%$ \\
\hline 13 & pAntp (47-58)-CPG2 & $81 \%$ & $79 \%$ \\
\hline 14 & II-CPG2 & $87 \%$ & $88 \%$ \\
\hline 15 & Crot (27-39) derevative 6-CPG2 & $81 \%$ & $85 \%$ \\
\hline 16 & Crot (27-39) derevative 7-CPG2 & $84 \%$ & $85 \%$ \\
\hline 17 & Crot (27-39) derevative 8-CPG2 & $85 \%$ & $83 \%$ \\
\hline 18 & Crot (27-39) derevative 9-CPG2 & $84 \%$ & $84 \%$ \\
\hline 19 & pAntp (46-58)-CPG2 & $81 \%$ & $80 \%$ \\
\hline 20 & 7-CPG2 & $70 \%$ & $74 \%$ \\
\hline 21 & No.14-2-CPG2 & $70 \%$ & $74 \%$ \\
\hline
\end{tabular}


Table 5. Cont.

\begin{tabular}{|c|c|c|c|}
\hline Peptide Number & Name of the Conjugate & $\begin{array}{c}\text { The Solubility } \\
\text { Percentage of } \\
\text { CPP-CPG2 N-Terminal } \\
\text { Conjugates }\end{array}$ & $\begin{array}{c}\text { The Solubility } \\
\text { Percentage of } \\
\text { CPG2-CPP C-Terminal } \\
\text { Conjugates }\end{array}$ \\
\hline 22 & No.14-CPG2 & $71 \%$ & $75 \%$ \\
\hline 23 & No.14-7-CPG2 & $70 \%$ & $74 \%$ \\
\hline 24 & Crot (27-39)-CPG2 & $84 \%$ & $83 \%$ \\
\hline 25 & Crot (27-39) derevative 10-CPG2 & $83 \%$ & $83 \%$ \\
\hline 26 & Crot (27-39) derevative 11-CPG2 & $83 \%$ & $83 \%$ \\
\hline 27 & Crot (27-39) derevative 12-CPG2 & $83 \%$ & $82 \%$ \\
\hline 28 & pVEC mutant $1-C P G 2$ & $80 \%$ & $80 \%$ \\
\hline 29 & pVEC mutant 2-CPG2 & $80 \%$ & $80 \%$ \\
\hline 30 & pVEC mutant 3-CPG2 & $78 \%$ & $77 \%$ \\
\hline 31 & Crot (27-39) derevative 13-CPG2 & $84 \%$ & $82 \%$ \\
\hline 32 & $\mathrm{ARF}(1-22)-\mathrm{CPG} 2$ & $75 \%$ & $76 \%$ \\
\hline 33 & M918-CPG2 & $75 \%$ & $76 \%$ \\
\hline 34 & pAntp (51-58)-CPG2 & $84 \%$ & $82 \%$ \\
\hline 35 & pAntp (44-58)-CPG2 & $79 \%$ & $79 \%$ \\
\hline 36 & pAntp (50-58)-CPG2 & $83 \%$ & $82 \%$ \\
\hline 37 & $\begin{array}{l}\text { Ala44 substitution mutant of } \\
\text { pAntp (43-58)-CPG2 }\end{array}$ & $79 \%$ & $78 \%$ \\
\hline 38 & PDX -1-PTD-CPG2 & $79 \%$ & $78 \%$ \\
\hline 39 & No.14-25-CPG2 & $73 \%$ & $75 \%$ \\
\hline 40 & No.14-17-CPG2 & $72 \%$ & $73 \%$ \\
\hline 41 & No.14-18-CPG2 & $71 \%$ & $72 \%$ \\
\hline 42 & No.14-20-CPG2 & $72 \%$ & $73 \%$ \\
\hline 43 & No.14-21-CPG2 & $72 \%$ & $73 \%$ \\
\hline 44 & No.14-35-CPG2 & $70 \%$ & $72 \%$ \\
\hline 45 & No.14-1-CPG2 & $71 \%$ & $72 \%$ \\
\hline 46 & 30-CPG2 & $72 \%$ & $74 \%$ \\
\hline 47 & $\begin{array}{l}\text { Ala45 substitution mutant of } \\
\text { pAntp (43-58)-CPG2 }\end{array}$ & $79 \%$ & $78 \%$ \\
\hline 48 & $\begin{array}{l}\text { Ala46 substitution mutant of } \\
\text { pAntp (43-58)-CPG2 }\end{array}$ & $78 \%$ & $76 \%$ \\
\hline 49 & $\begin{array}{l}\text { Ala47 substitution mutant of } \\
\text { pAntp (43-58)-CPG2 }\end{array}$ & $80 \%$ & $78 \%$ \\
\hline 50 & $\begin{array}{l}\text { Ala48 substitution mutant of } \\
\text { pAntp (43-58)-CPG2 }\end{array}$ & $81 \%$ & $80 \%$ \\
\hline 51 & $\begin{array}{l}\text { Ala49 substitution mutant of } \\
\text { pAntp (43-58)-CPG2 }\end{array}$ & $80 \%$ & $78 \%$ \\
\hline 52 & $\begin{array}{l}\text { Ala50 substitution mutant of } \\
\text { pAntp (43-58)-CPG2 }\end{array}$ & $79 \%$ & $78 \%$ \\
\hline 53 & pAntpHD (Pro50)-CPG2 & $79 \%$ & $78 \%$ \\
\hline 54 & $\begin{array}{l}\text { Ala51 substitution mutant of } \\
\text { pAntp (43-58)-CPG2 }\end{array}$ & $79 \%$ & $77 \%$ \\
\hline 55 & $\begin{array}{l}\text { Ala52 substitution mutant of } \\
\text { pAntp (43-58)-CPG2 }\end{array}$ & $80 \%$ & $79 \%$ \\
\hline 56 & Met-Arg-CPG2 & $79 \%$ & $78 \%$ \\
\hline 57 & $\begin{array}{l}\text { Ala54 substitution mutant of } \\
\text { pAntp (43-58)-CPG2 }\end{array}$ & $80 \%$ & $79 \%$ \\
\hline 58 & Penetratin-CPG2 & $79 \%$ & $78 \%$ \\
\hline 59 & Retro - Tat (57-49)-CPG2 & $82 \%$ & $81 \%$ \\
\hline 60 & R6-CPG2 & $80 \%$ & $82 \%$ \\
\hline 61 & R9-CPG2 & $77 \%$ & $79 \%$ \\
\hline 62 & Crot (27-39) derevative 14-CPG2 & $86 \%$ & $81 \%$ \\
\hline 63 & Crot (27-39) derevative 15-CPG2 & $85 \%$ & $81 \%$ \\
\hline 64 & $\operatorname{Rev}(34-50)-C P G 2$ & $73 \%$ & $74 \%$ \\
\hline 65 & HIV-1 Rev (34-50)-CPG2 & $74 \%$ & $73 \%$ \\
\hline 66 & Bip6-CPG2 & $84 \%$ & $85 \%$ \\
\hline 67 & Bip1-CPG2 & $84 \%$ & $85 \%$ \\
\hline 68 & Bip2-CPG2 & $84 \%$ & $85 \%$ \\
\hline 69 & Bip16-CPG2 & $83 \%$ & $85 \%$ \\
\hline \multirow[t]{2}{*}{70} & pAntp (48-58)-CPG2 & $82 \%$ & $79 \%$ \\
\hline & CPG2 & $83 \%$ & $83 \%$ \\
\hline
\end{tabular}




\subsection{Three-Dimensional Modeling of CPP-CPG2 and CPG2-CPP Conjugates}

CPPs might influence the structure and function of the covalently conjugated protein [54]. To deliver CPG2, the CPP segment in the conjugate should be exposed to interact with the functional groups on the plasma membrane. The CPP segment should not have any interactions with the active site of the enzyme to keep the functionality of the target protein unchanged. The conjugate should still have reasonable stereo-chemical characteristicw and low steric clashes leading to an easy folding. The I-TASSER program was used to generate PDB models. For each conjugate, models with the highest C-score value were selected and further analyzed by Ramachandran plots. In all models, the CPP domains were exposed and there were no interactions between CPPs and the active site of the CPG2 enzyme.

Residues in the most favored region and additionally allowed region of all Ramachandran plots exceeded $90 \%$, indicating that all models were reliable $[50,55,56]$. Compared to CPG2, $N$-terminal conjugates from peptides 9, 16, 17, 25, 54, and 62 and C-terminal conjugates from peptides 29, 39, and 69 had a higher number of residues in the most favored region of their Ramachandran plots (Table S5). Therefore, it seems that the N-terminal conjugates of "pAntp (49-58)-CPG2", "Ala51 substitution mutant of pAntp (43-58) -CPG2", "Crot (27-39) derivative 7-CPG2", "Crot (27-39) derivative 8-CPG2", "Crot (27-39) derivative 10-CPG2", and "Crot (27-39) derivative 14-CPG2", as well as "CPG2-pVEC mutant 2", "CPG2- Ala47 substitution mutant of pAntp (43-58)", and "CPG2-Bip16" C-terminal conjugates, have easier folding than unconjugated CPG2 (Figure 3 and Table S5). Furthermore, it should be noted that $N$-terminal CPP-CPG2 conjugates had a significantly higher number of residues in the most favored region compared with the C-terminal isoforms (Figure 4). Accordingly, $N$-terminal conjugates have sterically higher robustness.

(a) CPG2

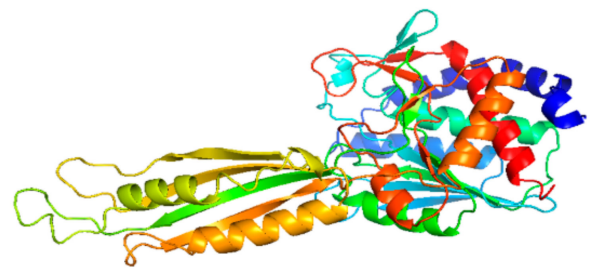

(b) Ala51 substitution mutant pAntp (43-58)-CPG2
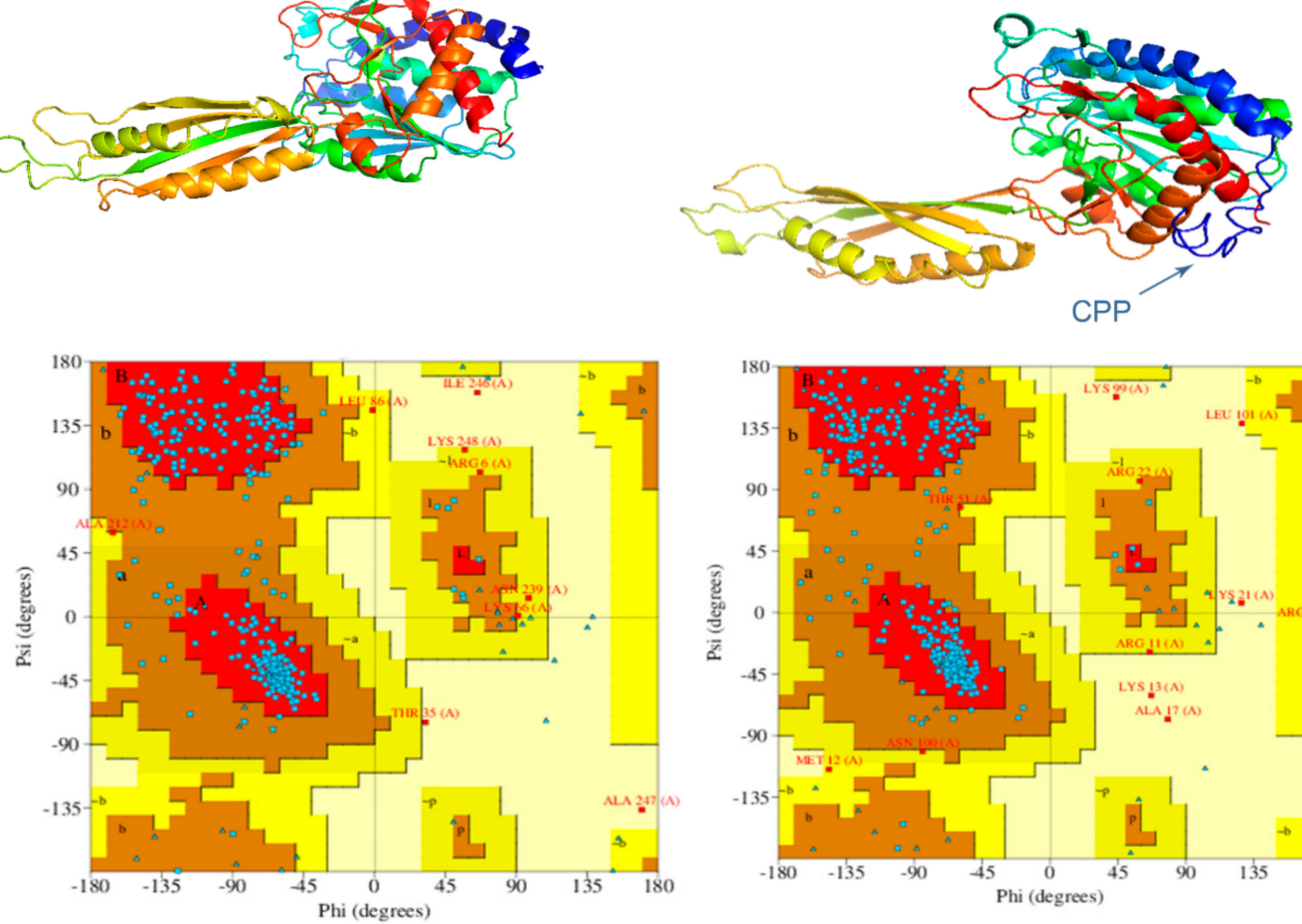

Figure 3. 3D models of (a) CPG2 and (b) "Ala51 substitution mutant of pAntp (43-58)" conjugated to the $N$-terminal position of CPG2 and their respective Ramachandran plots. 


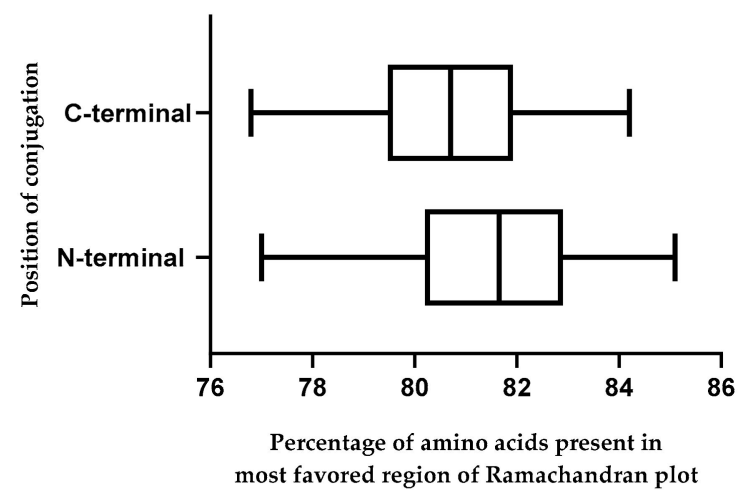

Figure 4. Distribution of percentage of amino acids present in the most favored region of Ramachandran plot across N- (CPP-CPG2) and C-terminal (CPG2-CPP) conjugates.

\subsection{Thermodynamic Characteristics of CPP-CPG2 and CPG2-CPP Conjugates}

Thermodynamic properties play an important role in developing stable biotherapeutics [57]. SCOOP server calculates thermodynamic quantities associated with the folding transition from unfolded to the native state, based on a protein's 3D structure and the host organism (Table 6, Table S6). The calculated parameters are co-related via the Gibbs-Helmholtz equation. According to the report of Pucci et al. [58], three main strategies result in a more thermodynamically stable protein. A more negative enthalpy change $\left(\Delta H_{S}\right)$ measured at the maximum stability temperature $\left(T_{S}\right)$ results in an overall decrease of $\Delta G$ at all temperatures. In the second strategy, the heat capacity upon folding $\left(\Delta C_{p}\right)$ becomes less negative, which yields an increase in melting temperature $\left(T_{m}\right)$. The last strategy consists of an increase in $T_{S}$ defined at the minimum of the $\Delta G(T)$ curve. As a result, one can find the most stable conjugated protein at room temperature by comparing folding free energy values at room temperature $\left(\Delta G_{r}\right)$. The conjugate's stability at higher temperatures can be associated with their corresponding $T_{m}$. Based on calculated values conjugates which have higher (or even equal) $\Delta G_{r}$ and $T_{m}$ compared with CPG2 are resulted from N-terminal conjugates with peptides 16, 21, 22, 36, 44, and 45 and C-terminal conjugation with peptides 16 and 63 (Table 6 and Table S6). The position of conjugation does not significantly affect any of the thermodynamic values calculated by SCOOP.

Table 6. Thermodynamic quantities of CPG2 and 70 top CPPs conjugated to CPG2 using the SCOOP server.

\begin{tabular}{|c|c|c|c|c|c|}
\hline \multirow{2}{*}{$\begin{array}{l}\text { Peptide } \\
\text { Number }\end{array}$} & \multirow[b]{2}{*}{ Name of the Conjugate } & \multicolumn{2}{|c|}{ N-Terminal Conjugates } & \multicolumn{2}{|c|}{ C-Terminal Conjugates } \\
\hline & & $T_{m}($ degree $\sim \mathrm{C})$ & $\begin{array}{l}\Delta G_{r} \\
\left(\mathrm{kcal} \mathrm{mol}^{-1}\right)\end{array}$ & $T_{m}($ degree $\sim \mathrm{C})$ & $\begin{array}{l}\Delta G_{r} \\
\left(\text { kcal.mol }^{-1}\right)\end{array}$ \\
\hline 1 & Transportan 10 (TP10)-CPG2 & 64.1 & -12.3 & 60.9 & -15.9 \\
\hline 2 & $\begin{array}{l}\text { Ala43 substitution mutant of pAntp } \\
(43-58)-C P G 2\end{array}$ & 59.1 & -13.1 & 60.7 & -11.6 \\
\hline 3 & Crot (27-39) derivative 1-CPG2 & 61.2 & -13.3 & 61.7 & -13.1 \\
\hline 4 & Crot (27-39) derivative 2-CPG2 & 60.7 & -14.2 & 61.7 & -13.1 \\
\hline 5 & Crot (27-39) derivative 3-CPG2 & 61.3 & -14.1 & 59.0 & -14.0 \\
\hline 6 & CyLoP-1-CPG2 & 62.0 & -13.2 & 61.5 & -13.6 \\
\hline 7 & Crot (27-39) derivative 4-CPG2 & 63.1 & -14.0 & 65.8 & -13.8 \\
\hline 8 & Crot (27-39) derivative 5-CPG2 & 62.4 & -13.1 & 60.2 & -15.0 \\
\hline 9 & pAntp (49-58)-CPG2 & 60.5 & -16.0 & 59.3 & -16.6 \\
\hline 10 & Tat (48-60)-CPG2 & 60.1 & -13.4 & 68.0 & -13.6 \\
\hline 11 & pAntp (45-58)-CPG2 & 59.1 & -16.1 & 60.0 & -14.1 \\
\hline 12 & Bip15-CPG2 & 60.7 & -12.7 & 63.1 & -14.4 \\
\hline 13 & pAntp (47-58)-CPG2 & 59.7 & -15.4 & 62.2 & -13.2 \\
\hline 14 & II-CPG2 & 59.7 & -15.4 & 62.5 & -14.8 \\
\hline 15 & Crot (27-39) derivative 6-CPG2 & 62.8 & -13.3 & 62.3 & -12.9 \\
\hline 16 & Crot (27-39) derivative 7-CPG2 & 61.7 & -15.9 & 64.1 & -15.2 \\
\hline 17 & Crot (27-39) derivative 8-CPG2 & 61.1 & -14.8 & 60.3 & -15.9 \\
\hline
\end{tabular}


Table 6. Cont.

\begin{tabular}{|c|c|c|c|c|c|}
\hline \multirow{2}{*}{$\begin{array}{l}\text { Peptide } \\
\text { Number }\end{array}$} & \multirow[b]{2}{*}{ Name of the Conjugate } & \multicolumn{2}{|c|}{ N-Terminal Conjugates } & \multicolumn{2}{|c|}{ C-Terminal Conjugates } \\
\hline & & $T_{m}$ (degree $\left.\sim \mathrm{C}\right)$ & $\begin{array}{l}\Delta G_{r} \\
\left(\text { kcal.mol }^{-1}\right)\end{array}$ & $T_{m}$ (degree $\left.\sim \mathrm{C}\right)$ & $\begin{array}{l}\Delta G_{r} \\
\left.\text { (kcal.mol }^{-1}\right)\end{array}$ \\
\hline 18 & Crot (27-39) derivative 9-CPG2 & 59.1 & -13.2 & 61.7 & -13.3 \\
\hline 19 & pAntp (46-58)-CPG2 & 63.0 & -12.7 & 61.2 & -14.6 \\
\hline 20 & 7-CPG2 & 62.7 & -12.8 & 60.2 & -12.8 \\
\hline 21 & No.14-2-CPG2 & 61.9 & -15.1 & 59.6 & -13.6 \\
\hline 22 & No.14-CPG2 & 64.7 & -15.4 & 59.8 & -14.8 \\
\hline 23 & No.14-7-CPG2 & 63.6 & -14.4 & 63.0 & -12.6 \\
\hline 24 & Crot (27-39)-CPG2 & 61.4 & -15.0 & 61.0 & -14.9 \\
\hline 25 & Crot (27-39) derivative 10-CPG2 & 60.6 & -14.7 & 57.3 & -13.0 \\
\hline 26 & Crot (27-39) derivative 11-CPG2 & 61.0 & -15.1 & 58.9 & -15.4 \\
\hline 27 & Crot (27-39) derivative 12-CPG2 & 60.5 & -13.6 & 59.5 & -13.9 \\
\hline 28 & pVEC mutant 1-CPG2 & 63.8 & -14.0 & 64.2 & -12.0 \\
\hline 29 & pVEC mutant 2-CPG2 & 60.2 & -16.8 & 57.9 & -15.8 \\
\hline 30 & pVEC mutant 3-CPG2 & 63.8 & -11.2 & 62.1 & -13.7 \\
\hline 31 & Crot (27-39) derivative 13-CPG2 & 64.2 & -14.3 & 58.5 & -13.3 \\
\hline 32 & ARF(1-22)-CPG2 & 61.0 & -16.3 & 65.4 & -12.4 \\
\hline 33 & M918-CPG2 & 65.5 & -14.8 & 63.3 & -12.6 \\
\hline 34 & pAntp (51-58)-CPG2 & 56.9 & -15.8 & 61.6 & -15.3 \\
\hline 35 & pAntp (44-58)-CPG2 & 58.1 & -13.6 & 59.5 & -16.8 \\
\hline 36 & pAntp (50-58)-CPG2 & 62.7 & -15.6 & 61.0 & -13.6 \\
\hline 37 & $\begin{array}{l}\text { Ala44 substitution mutant of pAntp } \\
\text { (43-58)-CPG2 }\end{array}$ & 60.7 & -13.8 & 58.4 & -15.6 \\
\hline 38 & PDX -1-PTD-CPG2 & 57.6 & -13.9 & 58.5 & -14.2 \\
\hline 39 & No.14-25-CPG2 & 62.3 & -11.5 & 58.5 & -15.3 \\
\hline 40 & No.14-17-CPG2 & 60.3 & -14.6 & 58.7 & -14.9 \\
\hline 41 & No.14-18-CPG2 & 60.6 & -13.3 & 61.6 & -13.9 \\
\hline 42 & No.14-20-CPG2 & 62.3 & -14.1 & 56.6 & -15.2 \\
\hline 43 & No.14-21-CPG2 & 63.8 & -14.8 & 60.8 & -14.2 \\
\hline 44 & No.14-35-CPG2 & 62.5 & -15.9 & 59.9 & -15.4 \\
\hline 45 & No.14-1-CPG2 & 61.7 & -15.5 & 60.7 & -13.4 \\
\hline 46 & $30-\mathrm{CPG} 2$ & 62.8 & -13.8 & 58.3 & -15.0 \\
\hline 47 & $\begin{array}{l}\text { Ala45 substitution mutant of pAntp } \\
\text { (43-58)-CPG2 }\end{array}$ & 60.2 & -14.0 & 59.7 & -16.3 \\
\hline 48 & $\begin{array}{l}\text { Ala } 46 \text { substitution mutant of pAntp } \\
(43-58)-C P G 2\end{array}$ & 63.2 & -12.9 & 60.4 & -14.6 \\
\hline 49 & $\begin{array}{l}\text { Ala47 substitution mutant of pAntp } \\
(43-58)-C P G 2\end{array}$ & 60.6 & -13.6 & 61.3 & -13.0 \\
\hline 50 & $\begin{array}{l}\text { Ala } 48 \text { substitution mutant of pAntp } \\
(43-58)-C P G 2\end{array}$ & 62.2 & -14.0 & 57.1 & -16.1 \\
\hline 51 & $\begin{array}{l}\text { Ala } 49 \text { substitution mutant of pAntp } \\
(43-58)-C P G 2\end{array}$ & 61.1 & -14.6 & 60.7 & -14.7 \\
\hline 52 & $\begin{array}{l}\text { Ala50 substitution mutant of pAntp } \\
(43-58) \text {-CPG2 }\end{array}$ & 60.8 & -13.3 & 59.5 & -15.3 \\
\hline 53 & pAntpHD (Pro50)-CPG2 & 62.7 & -12.7 & 60.7 & -13.4 \\
\hline 54 & $\begin{array}{l}\text { Ala51 substitution mutant of pAntp } \\
(43-58)-C P G\end{array}$ & 60.3 & -14.9 & 56.6 & -13.4 \\
\hline 55 & $\begin{array}{l}\text { Ala52 substitution mutant of pAntp } \\
\text { (43-58)-CPG2 }\end{array}$ & 63.9 & -11.9 & 61.1 & -13.4 \\
\hline 56 & Met-Arg-CPG2 & 64.2 & -14.3 & 59.6 & -14.3 \\
\hline 57 & $\begin{array}{l}\text { Ala54 substitution mutant of pAntp } \\
(43-58) \text {-CPG2 }\end{array}$ & 60.4 & -14.7 & 59.5 & -14.9 \\
\hline 58 & Penetratin-CPG2 & 60.4 & -15.1 & 60.0 & -12.5 \\
\hline 59 & Retro - Tat (57-49)-CPG2 & 61.0 & -14.0 & 60.4 & -14.7 \\
\hline 60 & R6-CPG2 & 58.7 & -14.3 & 62.0 & -14.4 \\
\hline 61 & R9-CPG2 & 62.7 & -13.8 & 57.7 & -15.5 \\
\hline 62 & Crot (27-39) derivative 14-CPG2 & 63.5 & -13.2 & 62.6 & -13.0 \\
\hline 63 & Crot (27-39) derivative 15-CPG2 & 60.3 & -13.6 & 63.0 & -15.1 \\
\hline 64 & $\operatorname{Rev}(34-50)-C P G 2$ & 59.1 & -16.4 & 58.5 & -16.0 \\
\hline 65 & HIV-1 Rev (34-50)-CPG2 & 62.0 & -13.3 & 59.9 & -15.2 \\
\hline 66 & Bip6-CPG2 & 62.6 & -15.0 & 62.6 & -13.9 \\
\hline 67 & Bip1-CPG2 & 56.7 & -14.9 & 63.4 & -11.2 \\
\hline 68 & Bip2-CPG2 & 60.8 & -13.7 & 60.5 & -13.0 \\
\hline 69 & Bip16-CPG2 & 61.8 & -14.6 & 61.4 & -14.3 \\
\hline \multirow[t]{2}{*}{70} & pAntp (48-58)-CPG2 & 56.5 & -15.6 & 59.5 & -13.5 \\
\hline & CPG2 & 61.7 & -15.1 & 61.7 & -15.1 \\
\hline
\end{tabular}


The stability of the conjugates was also evaluated using the FoldX Suite server (Table 7 and Table S7). According to Rahmatabadi et al. [55], among the dynamic quantities calculated by FoldX Suite, four energies, including total free energy, side-chain hydrogen bonds, solvation polar, and van der Waals clashes have significant correlation with the number of amino acids in the most favored region of Ramachandran Plot; hence, affecting the stability of a protein. Amidst CPP-CPG2 conjugates, $N$-terminal conjugates derived from peptides 1, 19, 20, 21, 37, 64 and C-terminal conjugates composed of peptides $9,32,44,47,55,56,61$, and 69 have the most negative $\Delta G$ values of side $H$ bond energies. Only the N-terminal conjugate of "Bip 6-CPG2" has more thermodynamically stable energies across all 4 categories compared with the unconjugated CPG2. Furthermore, it was concluded that the position of conjugation does not significantly affect the calculated thermodynamic energies of CPP and CPG2 conjugates.

Table 7. Result of the stability analyses of CPG2 and top 70 CPPs conjugated to CPG2 using the FoldX suite server.

\begin{tabular}{|c|c|c|c|c|c|}
\hline $\begin{array}{l}\text { Peptide } \\
\text { Number }\end{array}$ & Name of the Conjugate & \multicolumn{2}{|c|}{ N-Terminal Conjugates } & \multicolumn{2}{|c|}{ C-Terminal Conjugates } \\
\hline 2 & $\begin{array}{l}\text { Ala43 substitution mutant of } \\
\text { pAntp (43-58)-CPG2 }\end{array}$ & -122.58 & 276.34 & -116.80 & 290.77 \\
\hline 5 & Crot (27-39) derivative 3-CPG2 & -124.84 & 201.96 & -116.51 & 221.44 \\
\hline 6 & CyLoP-1-CPG2 & -114.78 & 222.25 & -121.71 & 237.72 \\
\hline 7 & Crot (27-39) derivative 4-CPG2 & -118.05 & 240.24 & -117.87 & 258.05 \\
\hline 8 & Crot (27-39) derivative 5-CPG2 & -111.72 & 242.79 & -122.19 & 226.79 \\
\hline 9 & pAntp (49-58)-CPG2 & -117.91 & 213.28 & -128.23 & 192.93 \\
\hline 14 & II-CPG2 & -118.36 & 220.02 & -120.90 & 269.15 \\
\hline 15 & Crot (27-39) derivative 6-CPG2 & -122.01 & 240.34 & -112.90 & 247.76 \\
\hline 16 & Crot (27-39) derivative 7-CPG2 & -114.80 & 218.64 & -104.19 & 264.74 \\
\hline 17 & Crot (27-39) derivative 8-CPG2 & -113.66 & 231.91 & -118.05 & 228.78 \\
\hline 18 & Crot (27-39) derivative 9-CPG2 & -129.44 & 213.50 & -116.83 & 261.88 \\
\hline 19 & pAntp (46-58)-CPG2 & -129.66 & 234.61 & -122.16 & 220.00 \\
\hline 20 & 7-CPG2 & -118.37 & 248.66 & -113.78 & 227.61 \\
\hline 21 & No.14-2-CPG2 & -128.25 & 266.61 & -106.97 & 305.73 \\
\hline 22 & No.14-CPG2 & -121.58 & 288.14 & -125.08 & 244.91 \\
\hline 23 & No.14-7-CPG2 & -106.30 & 268.12 & -120.60 & 253.67 \\
\hline 31 & Crot (27-39) derivative $13-C P G 2$ & -117.23 & 274.19 & -124.87 & 208.41 \\
\hline 32 & ARF(1-22)-CPG2 & -116.67 & 287.55 & -127.44 & 277.30 \\
\hline 33 & M918-CPG2 & -100.79 & 353.34 & -120.74 & 304.20 \\
\hline 34 & pAntp (51-58)-CPG2 & -120.11 & 213.01 & -119.48 & 227.21 \\
\hline 35 & pAntp (44-58)-CPG2 & -120.79 & 271.81 & -113.18 & 237.39 \\
\hline 36 & pAntp (50-58)-CPG2 & -117.81 & 219.53 & -116.73 & 245.44 \\
\hline 37 & $\begin{array}{l}\text { Ala44 substitution mutant of } \\
\text { pAntp (43-58)-CPG2 }\end{array}$ & -131.75 & 260.06 & -107.05 & 248.14 \\
\hline 38 & PDX -1-PTD-CPG2 & -118.12 & 230.27 & -123.45 & 254.56 \\
\hline 39 & No.14-25-CPG2 & -117.33 & 259.77 & -111.95 & 223.28 \\
\hline 40 & No.14-17-CPG2 & -122.74 & 201.85 & -124.49 & 287.89 \\
\hline
\end{tabular}


Table 7. Cont.

\begin{tabular}{|c|c|c|c|c|c|}
\hline \multirow{2}{*}{$\begin{array}{l}\text { Peptide } \\
\text { Number }\end{array}$} & \multirow{2}{*}{ Name of the Conjugate } & \multicolumn{2}{|c|}{ N-Terminal Conjugates } & \multicolumn{2}{|c|}{ C-Terminal Conjugates } \\
\hline & & $\begin{array}{l}\Delta \mathrm{G}_{\text {side }} \mathrm{H}_{\text {bond }} \\
\text { (kcal.mol }{ }^{-1} \text { ) }\end{array}$ & $\begin{array}{l}\Delta \mathrm{G}_{\text {total }} \\
\text { (kcal.mol }{ }^{-1} \text { ) }\end{array}$ & $\begin{array}{l}\Delta \mathrm{G}_{\text {side }} \mathrm{H}_{\text {bond }} \\
\text { (kcal.mol }^{-1} \text { ) }\end{array}$ & $\begin{array}{l}\Delta \mathrm{G}_{\text {total }} \\
\text { (kcal.mol-1) }\end{array}$ \\
\hline 41 & No.14-18-CPG2 & -110.20 & 279.65 & -111.53 & 235.99 \\
\hline 42 & No.14-20-CPG2 & -113.46 & 286.37 & -120.35 & 235.61 \\
\hline 43 & No.14-21-CPG2 & -123.65 & 306.20 & -103.28 & 271.59 \\
\hline 44 & No.14-35-CPG2 & -118.98 & 316.52 & -127.82 & 288.57 \\
\hline 45 & No.14-1-CPG2 & -117.56 & 288.64 & -111.92 & 232.73 \\
\hline 46 & 30-CPG2 & -114.00 & 274.45 & -112.39 & 225.22 \\
\hline 47 & $\begin{array}{l}\text { Ala45 substitution mutant of } \\
\text { pAntp (43-58)-CPG2 }\end{array}$ & -121.63 & 244.81 & -128.84 & 256.18 \\
\hline 48 & $\begin{array}{l}\text { Ala46 substitution mutant of } \\
\text { pAntp (43-58)-CPG2 }\end{array}$ & -114.00 & 258.27 & -109.97 & 275.43 \\
\hline 49 & $\begin{array}{l}\text { Ala47 substitution mutant of } \\
\text { pAntp (43-58)-CPG2 }\end{array}$ & -111.21 & 279.55 & -118.80 & 250.65 \\
\hline 50 & $\begin{array}{l}\text { Ala48 substitution mutant of } \\
\text { pAntp (43-58)-CPG2 }\end{array}$ & -115.90 & 215.33 & -113.15 & 225.09 \\
\hline 51 & $\begin{array}{l}\text { Ala49 substitution mutant of } \\
\text { pAntp (43-58)-CPG2 }\end{array}$ & -120.58 & 259.79 & -125.14 & 244.61 \\
\hline 52 & $\begin{array}{l}\text { Ala50 substitution mutant of } \\
\text { pAntp (43-58)-CPG2 }\end{array}$ & -122.21 & 266.42 & -117.50 & 275.80 \\
\hline 53 & pAntpHD (Pro50)-CPG2 & -116.73 & 247.08 & -113.98 & 279.80 \\
\hline 54 & $\begin{array}{l}\text { Ala51 substitution mutant of } \\
\text { pAntp (43-58)-CPG2 }\end{array}$ & -120.61 & 256.74 & -117.29 & 277.38 \\
\hline 55 & $\begin{array}{l}\text { Ala52 substitution mutant of } \\
\text { pAntp (43-58)-CPG2 }\end{array}$ & -114.28 & 273.55 & -127.58 & 224.55 \\
\hline 56 & Met-Arg-CPG2 & -120.88 & 294.89 & -130.43 & 225.80 \\
\hline 57 & $\begin{array}{l}\text { Ala54 substitution mutant of } \\
\text { pAntp (43-58)-CPG2 }\end{array}$ & -113.18 & 274.17 & -126.16 & 223.46 \\
\hline 58 & Penetratin-CPG2 & -114.09 & 237.56 & -114.95 & 232.56 \\
\hline 59 & Retro - Tat (57-49)-CPG2 & -104.71 & 239.28 & -115.58 & 209.58 \\
\hline 60 & R6-CPG2 & -108.43 & 215.13 & -120.23 & 219.49 \\
\hline 61 & R9-CPG2 & -126.43 & 207.16 & -138.39 & 218.37 \\
\hline 62 & Crot (27-39) derivative 14-CPG2 & -116.15 & 187.59 & -117.38 & 233.60 \\
\hline 63 & Crot (27-39) derivative 15-CPG2 & -109.48 & 259.98 & -112.67 & 226.84 \\
\hline 64 & $\operatorname{Rev}(34-50)-C P G 2$ & -140.73 & 250.30 & -120.99 & 267.37 \\
\hline 65 & HIV-1 Rev (34-50)-CPG2 & -123.81 & 241.35 & -120.42 & 237.54 \\
\hline 66 & Bip6-CPG2 & -126.11 & 176.25 & -117.74 & 237.91 \\
\hline 67 & Bip1-CPG2 & -120.74 & 163.93 & -125.52 & 199.54 \\
\hline 68 & Bip2-CPG2 & -106.63 & 227.56 & -122.97 & 213.03 \\
\hline 69 & Bip16-CPG2 & -118.69 & 199.30 & -126.85 & 187.15 \\
\hline \multirow[t]{2}{*}{70} & pAntp (48-58)-CPG2 & -121.70 & 239.55 & -125.92 & 230.92 \\
\hline & CPG2 & -124.91 & 203.85 & -124.91 & 203.85 \\
\hline
\end{tabular}

\subsection{Prediction of the Aggregation Possibility of CPP-CPG2 and CPG2-CPP Conjugates}

It has been demonstrated that depending on the surrounding conditions and structure, proteins can form insoluble, though stable constructs composed of amyloid fibrils or amorphous aggregates [59]. Protein aggregation is one of the troubles encountered in vitro and in vivo. Protein release and activity are distorted if aggregation occurs after delivery [60,61]. As a result, several computational strategies are used to determine the propensity of proteins to form amyloids based on their amino acid sequence [62-64]. Herein, we have employed two servers called Aggrescan and PASTA 2.0 to investigate if the addition of a CPP sequence to CPG2 affects the probability of protein aggregation. Aggrescan finds the number of hotspots for aggregation in a protein regarding amino acid composition, while PASTA 2.0 evaluates the chance of amyloid formations considering pairwise interactions within $\beta$-sheets. According to PASTA 2.0 calculations, there was no difference between the numbers of amyloid regions in the conjugates compared with unconjugated CPG2. However, based on Aggrescan analyses, $19 \mathrm{~N}$-terminal conjugates and $15 \mathrm{C}$-terminal conjugates displayed 17 aggregation hotspots, whereas CPG2 itself and the rest of the conjugates had 16 aggregation hot spots. As a result, $19 \mathrm{~N}$-terminal 
and $15 \mathrm{C}$-terminal conjugates might have an increased risk of aggregation than the non-fused CPG2 (Table S8).

\subsection{Folding Rate and Backbone Flexibility of CPP-CPG2 and CPG2-CPP Conjugates}

A protein chain has to be folded into its native conformation to be functional. Therefore, the conjugates must have folding rates closer to the unconjugated CPG2. This means that the attached CPP sequence should cause a minimum disturbance in the folding of a chimera. Although conjugates showed longer folding half-times compared with CPG2, $N$-terminal conjugates from peptides 8,10 , $18,34,36,59,66,68$, and 69 and C-terminal conjugates from peptides 12, 59, 60, 61, and 64 displayed the closest half folding time to the CPG2 itself (Table 8). Furthermore, regarding calculated values, $\mathrm{N}$-terminal CPP-CPG2 conjugates displayed significantly lower half-folding time compared with C-terminal conjugates (Figure 5).

Table 8. Result of folding rate prediction using the Foldrate server and backbone flexibility analysis by the Dynamine server for CPG2 and 70 top CPPs conjugated to CPG2.

\begin{tabular}{|c|c|c|c|}
\hline \multirow[b]{2}{*}{ Peptide Number } & \multirow[b]{2}{*}{ Name of the Conjugate } & N-Terminal Conjugates & C-Terminal Conjugates \\
\hline & & $\begin{array}{c}\text { Predicted Half-Folding } \\
\text { Time (sec) }\end{array}$ & $\begin{array}{c}\text { Predicted Half-Folding } \\
\text { Time (sec) }\end{array}$ \\
\hline 1 & Transportan 10 (TP10)-CPG2 & 315.75 & 292.07 \\
\hline 2 & $\begin{array}{l}\text { Ala43 substitution mutant of } \\
\text { pAntp (43-58)-CPG2 }\end{array}$ & 341.86 & 375.47 \\
\hline 3 & Crot (27-39) derivative 1-CPG2 & 269.35 & 294.03 \\
\hline 4 & Crot (27-39) derivative 2-CPG2 & 266.25 & 297.08 \\
\hline 5 & Crot (27-39) derivative 3-CPG2 & 266.25 & 297.08 \\
\hline 6 & CyLoP-1-CPG2 & 263.17 & 296.95 \\
\hline 7 & Crot (27-39) derivative 4-CPG2 & 290.06 & 299.60 \\
\hline 8 & Crot (27-39) derivative 5-CPG2 & 251.58 & 269.07 \\
\hline 9 & pAntp (49-58)-CPG2 & 260.00 & 265.84 \\
\hline 10 & Tat (48-60)-CPG2 & 250.01 & 261.29 \\
\hline 11 & pAntp (45-58)-CPG2 & 326.14 & 336.71 \\
\hline 12 & Bip15-CPG2 & 254.99 & 251.17 \\
\hline 13 & pAntp (47-58)-CPG2 & 312.02 & 325.60 \\
\hline 14 & II-CPG2 & 282.10 & 260.72 \\
\hline 15 & Crot (27-39) derivative 6-CPG2 & 272.11 & 300.16 \\
\hline 16 & Crot (27-39) derivative 7-CPG2 & 300.50 & 310.30 \\
\hline 17 & Crot (27-39) derivative 8-CPG2 & 262.57 & 286.80 \\
\hline 18 & Crot (27-39) derivative 9-CPG2 & 251.02 & 271.45 \\
\hline 19 & pAntp (46-58)-CPG2 & 314.64 & 324.84 \\
\hline 20 & $7-\mathrm{CPG} 2$ & 304.54 & 328.42 \\
\hline 21 & No.14-2-CPG2 & 303.00 & 306.34 \\
\hline 22 & No.14-CPG2 & 312.62 & 340.53 \\
\hline 23 & No.14-7-CPG2 & 288.59 & 325.49 \\
\hline 24 & Crot (27-39)-CPG2 & 262.67 & 283.81 \\
\hline 25 & Crot (27-39) derivative 10-CPG2 & 263.85 & 297.45 \\
\hline 26 & Crot (27-39) derivative 11-CPG2 & 287.51 & 303.33 \\
\hline 27 & Crot (27-39) derivative 12-CPG2 & 281.35 & 296.93 \\
\hline 28 & pVEC mutant 1-CPG2 & 318.66 & 318.66 \\
\hline 29 & pVEC mutant 2-CPG2 & 308.37 & 318.66 \\
\hline 30 & pVEC mutant 3-CPG2 & 331.94 & 310.97 \\
\hline 31 & Crot (27-39) derivative 13-CPG2 & 257.41 & 310.97 \\
\hline 32 & $\mathrm{ARF}(1-22)-\mathrm{CPG} 2$ & 375.57 & 426.04 \\
\hline 33 & M918-CPG2 & 371.56 & 371.56 \\
\hline 34 & pAntp (51-58)-CPG2 & 246.89 & 371.56 \\
\hline 35 & pAntp (44-58)-CPG2 & 341.31 & 359.69 \\
\hline 36 & pAntp (50-58)-CPG2 & 253.19 & 371.56 \\
\hline 37 & $\begin{array}{l}\text { Ala44 substitution mutant of } \\
\text { pAntp (43-58)-CPG2 }\end{array}$ & 339.30 & 371.56 \\
\hline 38 & PDX -1-PTD-CPG2 & 354.49 & 371.56 \\
\hline 39 & No.14-25-CPG2 & 302.06 & 325.92 \\
\hline 40 & No.14-17-CPG2 & 286.95 & 325.92 \\
\hline
\end{tabular}


Table 8. Cont.

\begin{tabular}{|c|c|c|c|}
\hline \multirow[b]{2}{*}{ Peptide Number } & \multirow[b]{2}{*}{ Name of the Conjugate } & \multirow{2}{*}{$\begin{array}{c}\text { N-Terminal Conjugates } \\
\text { Predicted Half-Folding } \\
\text { Time (sec) }\end{array}$} & \multirow{2}{*}{$\begin{array}{c}\text { C-Terminal Conjugates } \\
\text { Predicted Half-Folding } \\
\text { Time (sec) }\end{array}$} \\
\hline & & & \\
\hline 41 & No.14-18-CPG2 & 316.39 & 325.92 \\
\hline 42 & No.14-20-CPG2 & 300.29 & 325.92 \\
\hline 43 & No.14-21-CPG2 & 303.60 & 341.55 \\
\hline 44 & No.14-35-CPG2 & 309.58 & 341.55 \\
\hline 45 & No.14-1-CPG2 & 315.26 & 341.55 \\
\hline 46 & 30-CPG2 & 311.23 & 328.53 \\
\hline 47 & $\begin{array}{l}\text { Ala45 substitution mutant of } \\
\text { pAntp (43-58)-CPG2 }\end{array}$ & 321.46 & 368.26 \\
\hline 48 & $\begin{array}{l}\text { Ala46 substitution mutant of } \\
\text { pAntp (43-58)-CPG2 }\end{array}$ & 341.11 & 368.26 \\
\hline 49 & $\begin{array}{l}\text { Ala47 substitution mutant of } \\
\text { pAntp (43-58)-CPG2 }\end{array}$ & 301.29 & 364.51 \\
\hline 50 & $\begin{array}{l}\text { Ala48 substitution mutant of } \\
\text { pAntp (43-58)-CPG2 }\end{array}$ & 301.06 & 364.51 \\
\hline 51 & $\begin{array}{l}\text { Ala49 substitution mutant of } \\
\text { pAntp (43-58)-CPG2 }\end{array}$ & 328.09 & 338.69 \\
\hline 52 & $\begin{array}{l}\text { Ala50 substitution mutant of } \\
\text { pAntp (43-58)-CPG2 }\end{array}$ & 342.91 & 357.57 \\
\hline 53 & pAntpHD (Pro50)-CPG2 & 324.61 & 342.27 \\
\hline 54 & $\begin{array}{l}\text { Ala51 substitution mutant of } \\
\text { pAntp (43-58)-CPG2 }\end{array}$ & 342.47 & 342.27 \\
\hline 55 & $\begin{array}{l}\text { Ala52 substitution mutant of } \\
\text { pAntp (43-58)-CPG2 }\end{array}$ & 300.29 & 364.03 \\
\hline 56 & Met-Arg-CPG2 & 298.31 & 315.14 \\
\hline 57 & $\begin{array}{l}\text { Ala54 substitution mutant of } \\
\text { pAntp (43-58)-CPG2 }\end{array}$ & 295.42 & 305.35 \\
\hline 58 & Penetratin-CPG2 & 354.39 & 400.84 \\
\hline 59 & Retro - Tat (57-49)-CPG2 & 243.94 & 246.69 \\
\hline 60 & R6-CPG2 & 255.43 & 249.84 \\
\hline 61 & R9-CPG2 & 269.07 & 249.03 \\
\hline 62 & Crot (27-39) derivative 14-CPG2 & 258.50 & 276.26 \\
\hline 63 & Crot (27-39) derivative 15-CPG2 & 255.15 & 263.85 \\
\hline 64 & $\operatorname{Rev}(34-50)-C P G 2$ & 265.86 & 251.26 \\
\hline 65 & HIV-1 Rev (34-50)-CPG2 & 276.22 & 261.16 \\
\hline 66 & Bip6-CPG2 & 239.77 & 256.43 \\
\hline 67 & Bip1-CPG2 & 256.15 & 259.01 \\
\hline 68 & Bip2-CPG2 & 240.98 & 260.66 \\
\hline 69 & Bip16-CPG2 & 242.18 & 262.04 \\
\hline 70 & pAntp (48-58)-CPG2 & 300.95 & 278.92 \\
\hline & CPG2 & 229.89 & 229.89 \\
\hline
\end{tabular}

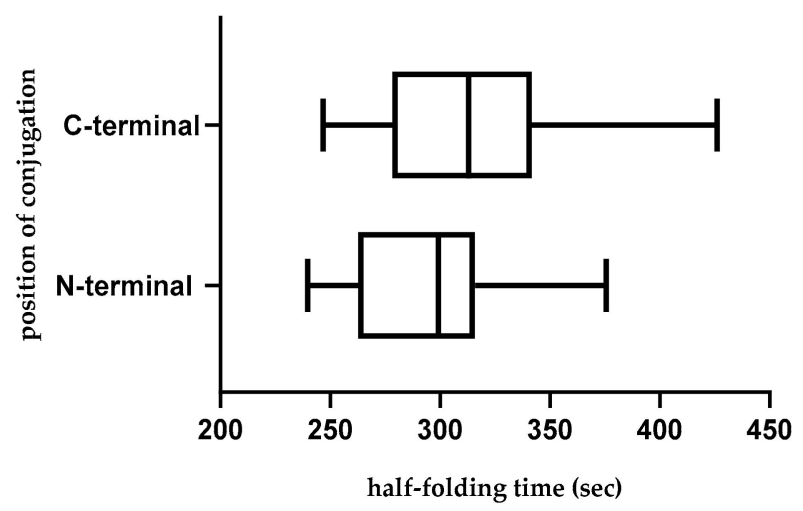

Figure 5. Distribution of half-folding time across N-terminal (CPP-CPG2) and C-terminal (CPG2-CPP) conjugates. 
Proteins are composed of a string of amino acids, which after some non-covalent interactions fold into naturally flexible tertiary structures. The degree of flexibility is associated with a protein's function and is crucial in protein engineering and rational drug design [65]. Ligand-binding sites in enzymes usually have both flexible and rigid residues. Rigid residues are associated with specificity and tightness of ligand binding, while flexibility facilitates the entrance of ligands into the binding site and can also be involved in the communication between allosteric and orthosteric binding sites $[66,67]$. It should be noted that in any enzyme-ligand interaction, the enzyme undergoes a conformational change; therefore, variations in the enzyme's flexibility might disrupt the function. Using the Dynamine server, each conjugate was evaluated to assess if the addition of CPP sequence to CPG2 interferes with the flexibility of zinc-binding amino acids $\left(\mathrm{His}^{89}, \mathrm{Asp}^{119}, \mathrm{Glu}^{154}, \mathrm{Glu}^{178}\right.$, and $\mathrm{His}^{363}$ ). This might intervene in the ability of CPG2 attachment to the zinc molecules that are substantial for the detoxification of MTX. No changes were observed in $\mathrm{His}^{89}, \mathrm{Asp}^{119}, \mathrm{Glu}^{154}, \mathrm{Glu}^{178}$, and $\mathrm{His}^{363}$ flexibility scores in any of the conjugates. It can be concluded that the addition of CPPs had no interference with the CPG2 ligand-binding site.

\subsection{Further Analyses for In Vivo Applications}

In vivo administration of biotherapeutics comes with a new set of challenges. The objective of this section was to select the conjugates best suited for in vivo application (Table 9).

\subsubsection{Analyses of CPP-CPG2 and CPG2-CPP Conjugates}

Some proteins might trigger mild to acute allergic responses and fatal anaphylactic shocks. Hence, the possibility of the allergenicity of a biotherapeutic should be explored. Hypersensitivity reactions were reported only in less than $1 \%$ of patients receiving glucarpidase [27]. Therefore, it should be investigated if the addition of a CPP sequence affects the probability of allergic reactions. Allergen FP V. 1.0 server evaluated CPG2 and all 140 CPP-CPG2/CPG2-CPP conjugates as probable non-allergens; thus, one can assume that the addition of these CPPs to the CPG2 sequence would not increase the enzyme's allergenicity considerably.

One of the other notable characteristics in a therapeutic is immunogenicity. If the patient's immune system recognizes a biotherapeutic as a threat, produced antibodies reduce the effectiveness of the medication after repeated use. Although glucarpidase does not result in hypersensitivity in most patients, studies have shown that anti-glucarpidase antibodies developed in $17 \%$ of patients receiving the medication for one or two doses [27]. In this regard, the fused CPP sequence preferably should not increase the antigenicity of CPG2 and if possible, alleviates the immunogenicity. Assessment of CPG2 and the top 70 CPPs conjugated to $\mathrm{N}$ - and C-terminal positions showed that CPG2 and all the conjugates had immunogenicity scores above 0.4 , which might act as potential antigens. The addition of CPP resulted in a decrease in immunogenicity score in most conjugates. About $66 \%$ of $N$-terminal and $60 \%$ of C-terminal conjugates had an immunogenicity score lower than that of CPG2. $N$-terminal conjugates from peptides 1, 14, 47, 48, 49 and C-terminal conjugates from peptides 14, 19, 29, 48, and 70 displayed the least immunogenicity scores. Furthermore, it was concluded that the position of conjugations does not significantly affect the immunogenicity of CPP and CPG2 conjugates.

One of the concerns for protein therapeutics is their short biological half-lives. Proteins usually have fast degradation and clearance either by kidney filtration or liver metabolism. In the case of CPP-CPG2 conjugates, intracellular proteasomes might also expedite the frequency of administration. This shows the importance of the selection of the conjugates with optimal predicted half-lives. Using the ProtLifePred server, it was shown that all C-terminal conjugates have half-lives comparable to the unconjugated CPG2, while $31 \%$ of the N-terminal conjugates had half-lives longer than the unconjugated control. The rest of the conjugates had shorter or equal half-lives compared with un-conjugated CPG2 (Table S9). 


\subsubsection{Analyses of top CPPs for In Vivo Application}

Some proteins and peptides might have hemolytic toxicity towards red blood cells. Hemolysis is the premature loss of RBCs before their 120 days of the expected lifespan, which results in anemia. According to the HemoPI tool, CPPs named "Transportan 10 (TP10)" and "II" with the highest PROB scores might potentially have hemolysis effect after in vivo administration. "pVEC" mutants and "Retro - Tat (57-49)" had the lowest possibility of hemolysis. All the other CPPs had equal PROB scores relatively.

Another aspect that one should consider in the design of biotherapeutics is the undesired proinflammatory effect of proteins and peptides. For vaccines or immunotherapeutics, the ultimate goal is the activation of the immune system; however, for other proteins, proinflammatory effects such as T cell or B cell activation is undesirable. Proinflamm server checks the peptide sequence for some recognized proinflammatory epitopes. In this study, no inflammatory potential for the top $70 \mathrm{CPPs}$ was detected.

As the aim of this study was to find the best candidates among experimentally validated CPPs for conjugations with CPG2, ToxinPred server was used to screen the top 70 CPPs using SVM based approach to identify toxic CPPs. Twenty percent of the top 70 CPPs were predicted to be toxic. All toxic peptides were derivatives of Crot (27-79), which originates from protein in snake venom. Unfortunately, no tool is available for the analysis of hemolytic activity and the proinflammatory effect of complete protein sequences.

Table 9. Analysis of top 70 CPPs and top 70 CPPs conjugated to CPG2 for in vivo application.

\begin{tabular}{|c|c|c|c|c|c|}
\hline \multirow{2}{*}{$\begin{array}{l}\text { Peptide } \\
\text { Number }\end{array}$} & \multirow{2}{*}{ CPPs' Name } & \multicolumn{2}{|c|}{$\begin{array}{l}\text { Immunogenicity of Respective } \\
\text { CPP-CPG2 /CPG2-CPP Conjugate }\end{array}$} & \multirow{2}{*}{$\begin{array}{l}\text { Toxicity of } \\
\text { CPPs }\end{array}$} & \multirow{2}{*}{$\begin{array}{c}\text { Hemolysis Potency } \\
\text { of CPPs } \\
\text { (PROB Score) }\end{array}$} \\
\hline & & $\begin{array}{l}\text { N-Terminal } \\
\text { Conjugates }\end{array}$ & $\begin{array}{l}\text { C-Terminal } \\
\text { Conjugates }\end{array}$ & & \\
\hline 1 & $\begin{array}{l}\text { Transportan } 10 \\
\text { (TP10) }\end{array}$ & 0.6620 & 0.6790 & non-toxin & 0.83 \\
\hline 2 & $\begin{array}{l}\text { Ala43 substitution } \\
\text { mutant of pAntp } \\
(43-58)\end{array}$ & 0.6874 & 0.6907 & non-toxin & 0.48 \\
\hline 3 & $\begin{array}{l}\text { Crot }(27-39) \\
\text { derivative } 1\end{array}$ & 0.7201 & 0.7267 & Toxin & 0.49 \\
\hline 4 & $\begin{array}{l}\text { Crot }(27-39) \\
\text { derivative } 2\end{array}$ & 0.7199 & 0.7263 & Toxin & 0.49 \\
\hline 5 & $\begin{array}{l}\text { Crot }(27-39) \\
\text { derivative } 3\end{array}$ & 0.7238 & 0.7319 & Toxin & 0.49 \\
\hline 6 & CyLoP-1 & 0.7244 & 0.7323 & Toxin & 0.49 \\
\hline 7 & $\begin{array}{l}\text { Crot }(27-39) \\
\text { derivative } 4\end{array}$ & 0.7361 & 0.7403 & non-toxin & 0.49 \\
\hline 8 & $\begin{array}{l}\text { Crot }(27-39) \\
\text { derivative } 5\end{array}$ & 0.7276 & 0.7334 & Toxin & 0.49 \\
\hline 9 & pAntp (49-58) & 0.6973 & 0.7017 & non-toxin & 0.48 \\
\hline 10 & Tat (48-60) & 0.7208 & 0.7385 & non-toxin & 0.49 \\
\hline 11 & pAntp (45-58) & 0.6910 & 0.6794 & non-toxin & 0.49 \\
\hline 12 & Bip15 & 0.6929 & 0.6903 & non-toxin & 0.49 \\
\hline 13 & pAntp (47-58) & 0.6855 & 0.6690 & non-toxin & 0.48 \\
\hline 14 & II & 0.6466 & 0.6521 & non-toxin & 0.83 \\
\hline 15 & $\begin{array}{l}\text { Crot }(27-39) \\
\text { derivative } 6\end{array}$ & 0.7219 & 0.7300 & Toxin & 0.49 \\
\hline
\end{tabular}


Table 9. Cont.

\begin{tabular}{|c|c|c|c|c|c|}
\hline \multirow{2}{*}{$\begin{array}{l}\text { Peptide } \\
\text { Number }\end{array}$} & \multirow{2}{*}{ CPPs' Name } & \multicolumn{2}{|c|}{$\begin{array}{l}\text { Immunogenicity of Respective } \\
\text { CPP-CPG2 /CPG2-CPP Conjugate }\end{array}$} & \multirow{2}{*}{$\begin{array}{l}\text { Toxicity of } \\
\text { CPPs }\end{array}$} & \multirow{2}{*}{$\begin{array}{c}\text { Hemolysis Potency } \\
\text { of CPPs } \\
\text { (PROB Score) }\end{array}$} \\
\hline & & $\begin{array}{l}\text { N-Terminal } \\
\text { Conjugates }\end{array}$ & $\begin{array}{l}\text { C-Terminal } \\
\text { Conjugates }\end{array}$ & & \\
\hline 16 & $\begin{array}{l}\text { Crot }(27-39) \\
\text { derivative } 7\end{array}$ & 0.7439 & 0.7410 & non-toxin & 0.49 \\
\hline 17 & $\begin{array}{l}\text { Crot }(27-39) \\
\text { derivative } 8\end{array}$ & 0.7267 & 0.7314 & Toxin & 0.49 \\
\hline 18 & $\begin{array}{l}\text { Crot }(27-39) \\
\text { derivative } 9\end{array}$ & 0.7263 & 0.7363 & Toxin & 0.49 \\
\hline 19 & pAntp (46-58) & 0.6813 & 0.6764 & non-toxin & 0.49 \\
\hline 20 & 7 & 0.6942 & 0.6961 & non-toxin & 0.49 \\
\hline 21 & No.14-2 & 0.6961 & 0.6980 & non-toxin & 0.49 \\
\hline 22 & No.14 & 0.6915 & 0.6934 & non-toxin & 0.49 \\
\hline 23 & No.14-7 & 0.6844 & 0.6863 & non-toxin & 0.49 \\
\hline 24 & Crot (27-39) & 0.7371 & 0.7409 & Toxin & 0.49 \\
\hline 25 & $\begin{array}{l}\text { Crot }(27-39) \\
\text { derivative } 10\end{array}$ & 0.7366 & 0.7388 & Toxin & 0.49 \\
\hline 26 & $\begin{array}{l}\text { Crot }(27-39) \\
\text { derivative } 11\end{array}$ & 0.7344 & 0.7406 & Toxin & 0.49 \\
\hline 27 & $\begin{array}{l}\text { Crot }(27-39) \\
\text { derivative } 12\end{array}$ & 0.7307 & 0.7327 & non-toxin & 0.49 \\
\hline 28 & pVEC mutant 1 & 0.7006 & 0.6886 & non-toxin & 0.32 \\
\hline 29 & pVEC mutant 2 & 0.6874 & 0.6755 & non-toxin & 0.32 \\
\hline 30 & pVEC mutant 3 & 0.6901 & 0.6782 & non-toxin & 0.31 \\
\hline 31 & $\begin{array}{l}\text { Crot (27-39) } \\
\text { derivative } 13\end{array}$ & 0.7304 & 0.7344 & Toxin & 0.49 \\
\hline 32 & $\operatorname{ARF}(1-22)$ & 0.6848 & 0.6917 & non-toxin & 0.48 \\
\hline 33 & M918 & 0.6865 & 0.6893 & non-toxin & 0.48 \\
\hline 34 & pAntp (51-58) & 0.7023 & 0.7142 & non-toxin & 0.49 \\
\hline 35 & pAntp (44-58) & 0.6892 & 0.6913 & non-toxin & 0.49 \\
\hline 36 & pAntp (50-58) & 0.7037 & 0.7153 & non-toxin & 0.49 \\
\hline 37 & $\begin{array}{l}\text { Ala44 substitution } \\
\text { mutant of pAntp } \\
(43-58)\end{array}$ & 0.6840 & 0.6866 & non-toxin & 0.48 \\
\hline 38 & PDX -1-PTD & 0.6845 & 0.6861 & non-toxin & 0.49 \\
\hline 39 & No.14-25 & 0.6910 & 0.6907 & non-toxin & 0.49 \\
\hline 40 & No.14-17 & 0.6889 & 0.6900 & non-toxin & 0.49 \\
\hline 41 & No.14-18 & 0.6927 & 0.6938 & non-toxin & 0.49 \\
\hline 42 & No.14-20 & 0.6922 & 0.6933 & non-toxin & 0.48 \\
\hline 43 & No.14-21 & 0.6949 & 0.6961 & non-toxin & 0.48 \\
\hline 44 & No.14-35 & 0.6924 & 0.6938 & non-toxin & 0.49 \\
\hline 45 & No.14-1 & 0.6929 & 0.6941 & non-toxin & 0.49 \\
\hline 46 & 30 & 0.6981 & 0.7012 & non-toxin & 0.49 \\
\hline 47 & $\begin{array}{l}\text { Ala45 substitution } \\
\text { mutant of pAntp } \\
(43-58)\end{array}$ & 0.6741 & 0.6817 & non-toxin & 0.47 \\
\hline
\end{tabular}


Table 9. Cont.

\begin{tabular}{|c|c|c|c|c|c|}
\hline \multirow{2}{*}{$\begin{array}{l}\text { Peptide } \\
\text { Number }\end{array}$} & \multirow{2}{*}{ CPPs' Name } & \multicolumn{2}{|c|}{$\begin{array}{l}\text { Immunogenicity of Respective } \\
\text { CPP-CPG2 /CPG2-CPP Conjugate }\end{array}$} & \multirow{2}{*}{$\begin{array}{l}\text { Toxicity of } \\
\text { CPPs }\end{array}$} & \multirow{2}{*}{$\begin{array}{c}\text { Hemolysis Potency } \\
\text { of CPPs } \\
\text { (PROB Score) }\end{array}$} \\
\hline & & $\begin{array}{l}\text { N-Terminal } \\
\text { Conjugates }\end{array}$ & $\begin{array}{l}\text { C-Terminal } \\
\text { Conjugates }\end{array}$ & & \\
\hline 48 & $\begin{array}{l}\text { Ala46 substitution } \\
\text { mutant of pAntp } \\
\text { (43-58) }\end{array}$ & 0.6756 & 0.6765 & non-toxin & 0.47 \\
\hline 49 & $\begin{array}{l}\text { Ala47 substitution } \\
\text { mutant of pAntp } \\
\text { (43-58) }\end{array}$ & 0.6740 & 0.6779 & non-toxin & 0.47 \\
\hline 50 & $\begin{array}{l}\text { Ala48 substitution } \\
\text { mutant of pAntp } \\
\text { (43-58) }\end{array}$ & 0.7007 & 0.7046 & non-toxin & 0.48 \\
\hline 51 & $\begin{array}{c}\text { Ala49 substitution } \\
\text { mutant of pAntp } \\
(43-58)\end{array}$ & 0.6784 & 0.6823 & non-toxin & 0.48 \\
\hline 52 & $\begin{array}{l}\text { Ala50 substitution } \\
\text { mutant of pAntp } \\
(43-58)\end{array}$ & 0.6827 & 0.6865 & non-toxin & 0.48 \\
\hline 53 & pAntpHD (Pro50) & 0.6887 & 0.6926 & non-toxin & 0.49 \\
\hline 54 & $\begin{array}{l}\text { Ala51 substitution } \\
\text { mutant of pAntp } \\
(43-58)\end{array}$ & 0.6878 & 0.6916 & non-toxin & 0.48 \\
\hline 55 & $\begin{array}{l}\text { Ala52 substitution } \\
\text { mutant of pAntp } \\
\text { (43-58) }\end{array}$ & 0.6932 & 0.6970 & non-toxin & 0.48 \\
\hline 56 & Met-Arg & 0.6792 & 0.6833 & non-toxin & 0.48 \\
\hline 57 & $\begin{array}{l}\text { Ala54 substitution } \\
\text { mutant of pAntp } \\
\quad(43-58)\end{array}$ & 0.6791 & 0.6828 & non-toxin & 0.48 \\
\hline 58 & Penetratin & 0.6820 & 0.6859 & non-toxin & 0.48 \\
\hline 59 & Retro - Tat (57-49) & 0.7094 & 0.7274 & non-toxin & 0.17 \\
\hline 60 & R6 & 0.6983 & 0.7184 & non-toxin & 0.49 \\
\hline 61 & R9 & 0.7084 & 0.7284 & non-toxin & 0.49 \\
\hline 62 & $\begin{array}{c}\text { Crot (27-39) } \\
\text { derivative } 14\end{array}$ & 0.7263 & 0.7208 & Toxin & 0.49 \\
\hline 63 & $\begin{array}{l}\text { Crot }(27-39) \\
\text { derivative } 15\end{array}$ & 0.7182 & 0.7284 & Toxin & 0.49 \\
\hline 64 & $\operatorname{Rev}(34-50)$ & 0.7032 & 0.7193 & non-toxin & 0.49 \\
\hline 65 & HIV-1 Rev (34-50) & 0.7128 & 0.7213 & non-toxin & 0.48 \\
\hline 66 & Bip6 & 0.6956 & 0.6980 & non-toxin & 0.49 \\
\hline 67 & Bip1 & 0.6920 & 0.6924 & non-toxin & 0.49 \\
\hline 68 & Bip2 & 0.6945 & 0.6984 & non-toxin & 0.49 \\
\hline 69 & Bip16 & 0.6957 & 0.6968 & non-toxin & 0.49 \\
\hline \multirow[t]{2}{*}{70} & pAntp (48-58) & 0.6838 & 0.6695 & non-toxin & 0.47 \\
\hline & CPG2 & 0.7012 & 0.7012 & - & - \\
\hline
\end{tabular}

\subsection{Effect of Position of Conjugations on CPP-CPG2 and CPG2-CPP Conjugates}

Throughout this study, the effect of position of the conjugation on the characteristics of all CPP-CPG2 and CPG2-CPP conjugates was analyzed using the unpaired t-test. The energy level of secondary structures at the $5^{\prime}$ mRNA's initiation translation region, robustness in the protein's 3D structures, higher helix and sheet content in the CPP region of the secondary structure after 
conjugation, and shorter half-folding times were all significantly improved in the N-terminal CPP-CPG2 conjugates compared with the C-terminal CPG2-CPP homologs. Regarding other features, including physiochemical properties, solubility, thermodynamic properties, probability of aggregation, backbone flexibility, allergenicity, and immunogenicity the position of conjugations was not significantly different between $\mathrm{N}$ - and C-terminal conjugates.

\subsection{Most Promising CPP Candidates to Design CPP-CPG2/CPG2-CPP Conjugates}

CPPs might influence the characteristics of the cargo protein of varying degrees. The ideal CPP for a conjugation would be the one that leads to the most favorable characteristics in the conjugate. As a result, “Bip 2", “Bip 6", “Bip 15”, "pAntp (45-58)”, “pAntp (46-58)”, " pAntp (47-58)”, "pAntp (48-58)", "pAntp (49-58)", "pAntp (51-58)”, "Ala44 substitution mutant of pAntp (43-58)”, "Ala52 substitution mutant of pAntp (43-58)", "Tat (48-60)", "Rev (34-50)", and "Crot (27-39) derivative 7" were CPPs with the highest desirable evaluated characteristics in N-terminal conjugation to CPG2. "Bip 1", "No.14-25", and "No.14-35" were the most promising CPPs for the C-terminus (Table S10). These seventeen CPP candidates can be categorized into five families:

(1) HIV-Tat and Its Derivatives:

Tat peptide is derived from the transcription transactivator protein of the HIV-1 virus. Tat has been successfully used in conjugation with a variety of molecules such as peptides, proteins, liposomes, nanoparticles, and nucleic acids [68]. In this study, "Tat (48-60)" and one of its derivatives "Rev (34-50)" are on our final candidate list. This is in agreement with our recent findings, wherein we have demonstrated experimentally the efficient intracellular delivery of CPG2 conjugated to the TAT peptide [28]. Both native and denatured forms of the enzyme transduced efficiently into the HepG2 cells in a concentration- and time-dependent manner. We have observed that in cells pretreated with TAT-CPG2 protein, the viability in the presence of MTX increased up to $98.63 \%$ compared with the control group, which had a viability of about $44.37 \%$. Hence, TAT-CPG2 was introduced as a strong protector of HepG2 cells against MTX-induced cell death.

(2) Penetratin Derivatives:

After the discovery of Tat, the penetratin peptide, which is derived from the amphiphilic Drosophila Antennapedia homeodomain (amino acids 43-58 of the homeodomain) was introduced as a CPP [69]. Currently, penetratin based therapeutics are being examined in vivo [70]. Eight CPPs from our final candidates including "pAntp (45-58)", "pAntp (46-58)”, "pAntp (47-58)”, " pAntp (48-58)”, " pAntp (49-58)", "pAntp (51-58)", "Ala44 substitution mutant of pAntp (43-58)", and "Ala52 substitution mutant of pAntp (43-58)" in the N-terminal conjugates are from this family.

(3) Crot (27-39) Derivatives:

Crotamin, a toxin found in snake venom, has two nuclear localization domains, named crot (2-18) and crot (27-39). Various derivatives of Crot (27-39) CPP with the original amino acid sequence of "KMDCRWRWKCCKK" are developed using amino acid substitution, deletion, or addition [49]. "Crot (27-39) derivative 7" from our candidate list belongs to this family.

\section{(4) Cell-Penetrating Pentapeptides (CPP5s):}

This group is designed according to the Bax-binding domain of Ku70 protein. Ku70 exerts cytoprotective effect by binding to Bax (a pro-apoptotic protein) and blocking its activation. Several cell-penetrating anti-apoptotic pentamer peptide sequences were designed based on the Bax-binding domain of Ku70. Subsequently, other CPP5s were developed by scrambling the sequence [71,72]. All five CPP5s are on our final candidates' list, including "Bip 2", "Bip 6" and "Bip 15" in the N-terminal conjugates, as well as "Bip 1", in the C-terminal conjugates to CPG2. Among these CPP5s, "Bip 1", "Bip 2", and "Bip 6" have cytoprotective properties, while "Bip 15" is without any cytoprotective 
effects [37,73]. Therefore, for the elimination of MTX and cytoprotective purposes, "Bip 1", "Bip 2", and "Bip6" might have further beneficial effects in conjugation to CPG2.

(5) Peptide No. 14 Derivatives:

This family of peptides was invented using an in vitro virus library to design CPPs with high transduction efficacy. These CPPs displayed higher uptake efficacy compared with TAT in some cell lines [36]. Furthermore, these peptides are sequentially similar to tumor lineage-homing cellpenetrating peptides [35]. Peptides named "No.14-25" and "No.14-35" from our most promising candidates in C-terminal conjugates belongs to this group of peptides.

\subsection{Analysis of Susceptibility to Human Proteases}

Proteases are a group of enzymes that can cleave the peptide backbone of their target proteins. Some proteases are only able to recognize and cleave particular amino acid sequences known as cleavage sites. Proteolytic degradation of peptides and protein-based drugs is one of the major complications on the way of achieving optimum systemic administration of therapeutics [74]. Glucarpidase, like other peptide and protein-based biotherapeutics, is prone to proteolytic degradation. Although its stability in the blood is high enough to eliminate high concentrations of blood MTX, this might not be enough for successful application in ADEPT [75]. Therefore, several strategies have been applied to increase the resistance of glucarpidase to proteolytic enzymes, such as PEGylation, fusion with human serum albumin [76,77], and circular permutations [75].

Using the Prosperous server, CPG2 and the most promising conjugates (17 final conjugates) were evaluated against human proteases (Tables S11 and S12). The protease susceptibility of the conjugates is similar to the unconjugated CPG2, except for "Rev (34-50)-CPG2" that had a significant chance of being cleaved by "Kallikrein related peptidase 5", while CPG2 and other CPP-CPG2 conjugates are expected to be resistant in the presence of the above-mentioned peptidase. It was observed that in some instances CPP-CPG2 conjugates had higher numbers of cleavage sites compared with CPG2 due to the addition of CPP sequence. However, the significant increase in cleavage sites has been observed for those proteases that target the unconjugated CPG2 even before the conjugation. Furthermore, some enzymes, for example, proprotein convertase 1 and 2, furin, and thrombin were able to cut inside the CPP sequence conjugated to CPG2. It could also be observed that the conjugation of CPP to CPG2 did not significantly decrease the protease susceptibility of CPG2.

\subsection{Limitations of the Current Study}

The mechanism of CPP translocation across plasma membranes is highly dependent on the type of cell line, the concentration of CPP, and the type of cargo [78]. Several CPPs can directly pass through the plasma membrane [79]; however, some others-especially those that are conjugated to macromolecules-penetrate through the endocytosis pathway. Endocytosis might result in the entrapment of the conjugate inside the endocytic organelles before arrival to the cytoplasmic or nuclear target [80]. Hence, the entrapment of CPPs and the corresponding conjugates inside the endosome is one of the limitations in the current computational and experimental studies. Although a bioinformatics method for the assessment of possible entrapment of CPP-protein conjugates is not available yet, using multivalent CPPs or CPP conjugation to a $\mathrm{pH}$-Dependent Membrane Active Peptide (PMAP) are recommended to resolve inadequate CPP-protein endosomal release issues [79]. However, it was promising that in our experimental study conducted on the $\mathrm{N}$-terminal conjugate of TAT-CPG2, the release of CPP-cargo conjugates from endosomes was high to display adequate pharmacological responses [28]. 


\section{Materials and Methods}

\subsection{Primary Dataset Collection}

Sequences of CPPs were retrieved from CPP site 2.0 (http://crdd.osdd.net/raghava/cppsite/), which keeps the records of experimentally validated CPPs [17]. After excluding cyclic peptides and CPPs that had un-natural residues or amino acids with D-conformations, 1155 unique CPPs remained. Although some of the excluded CPPs-CPPs with unnatural or D-conformation residues and cyclic CPPs-have shown promising results in experimental studies [81-83], current computational web servers are unable to analyze these sequences. Mature CPG2 amino acid sequence from Pseudomonas sp. strain RS-16 was retrieved from Uniprot (Uniprot ID \# P06621) to build protein conjugates. The nucleotide sequence of the $c p g 2$ gene was then codon-optimized by the codon usage wrangler server (https://www.mrc-lmb.com.ac.uk/ms/methods/codon.html).

\subsection{Penetration Prediction of $C P P S$}

The uptake efficiency and respective prediction confidence for all 1155 CPPs was predicted using the CPPred-RF server (http://server.malab.cn/CPPred-RF/) [84]. Results of CPPred-RF sever analysis was narrowed down to 70 CPP candidates, which have the highest uptake efficiency with the prediction confidence of 0.9 or above.

\section{3. $m R N A$ Secondary Structure Prediction of cpg2 and cpp-cpg2/cpg2-cpp Conjugates}

The nucleotide sequences of $c p g 2$ and top 70 cpps conjugated to either $\mathrm{N}$ - or C-terminus of $c p g 2$ gene in PET 14b expression vector (cpp-cpg2-pET14b) were used to determine the secondary structure and the minimum free energy of $5^{\prime}$-mRNA translation initiation region using the mfold online server (http://unafold.rna.albany.edu/?q=DINAMelt/Quickfold) [85]. To construct the N-terminal conjugates, 30 bases upstream of the start codon in PET 14b were fused to 30 initial bases of cpps linked to the codon-optimized $c p g 2$ gene. For the C-terminal conjugates, 30 bases upstream of the start codon were directly connected to the codon-optimized cpg2. PET 14b was selected due to our recent success in the expression of cpg2 and tat-cpg2 fusion constructs [28].

\subsection{Prediction of Physiochemical Properties of CPPs and CPP-CPG2/CPG2-CPP Conjugates}

Physiochemical properties of CPG2, N-terminal CPP-CPG2 and C-terminal CPG2-CPP conjugates, as well as the top $70 \mathrm{CPPs}$ alone, including molecular weight (Mw), isoelectric point (pI), instability index, GRAVY, and aliphatic index were calculated using ProtParam tool (http://web.expasy.org/ protparam/) [86].

\subsection{Solubility Prediction of CPG2 and CPP-CPG2/CPG2-CPP Conjugates}

The solubility of CPG2 and the top 70 CPPs linked to either $N$ - or C-terminus of CPG2 was calculated using the ccSol server (http://s.tartaglialab.com/page/ccsol_group) [87].

\subsection{Modeling 3D Structures of CPG2 and CPP-CPG2/CPG2-CPP Conjugates}

FASTA sequences of CPG2 and the top 70 CPPs as $N$ - and C-terminal conjugates to CPG2 were submitted to the Iterative Threading ASSEmbly Refinement (I-TASSER) program (https://zhanglab. ccmb.med.umich.edu/I-TASSER/) [88,89]. The most confident models (highest C-score value) derived from I-TASSER were uploaded to the PDBsum Generate EMBL-EBI (https://www.ebi.ac.uk/thorntonsrv/databases/pdbsum/Generate.html) [90]. Subsequently, PDBsum (http://www.ebi.ac.uk/thorntonsrv/databases/pdbsum) generated a Ramachandran plot for each model [91]. Ramachandran plots were analyzed for the most favored and additional allowed conformational regions. CPPs' secondary structures after their conjugation to CPG2 in the models also were noted. 


\subsection{Thermodynamic Quantities of CPG2 and CPP-CPG2/CPG2-CPP Conjugates}

PDB models of CPG2 and CPP-CPG2 N- and C-terminal conjugates were submitted to the SCOOP (http://babylone.ulb.ac.be/SCooP/k_query.php) [92] and FoldX (http://foldx.embl.de/) web servers [93]. SCOOP predicts the melting temperature $\left(T_{m}\right)$, changes in enthalpy $\left(\Delta H_{m}\right)$, heat capacity upon folding $\left(\Delta C_{p}\right)$, and the folding free energy at room temperature $\left(\Delta G_{r}\right)$. Using FoldX Suite, some of the stability features including total free energy, side-chain hydrogen bond (Side H bond), solvation polar (solp), and Van der Waals clashes (VdW clash) energies were calculated.

\subsection{Prediction of Aggregation Possibility of CPG2 and CPP-CPG2/CPG2-CPP Conjugates}

FASTA sequences of CPG2 and the top 70 CPPs linked to the N- and C-terminus of CPG2 were submitted to PASTA 2.0 (http://protein.bio.unipd.it/pasta2/) [94] and Aggrescan (http://bioinf.uab.es/ aggrescan/) [63] servers to compare aggregation possibility of conjugated versus un-conjugated CPG2 protein. PASTA 2.0 analyzes segments that are more likely to form fibrillar aggregates, and Aggrescan predicts the number of hot spots for aggregation in a sequence.

\subsection{Folding Rate of CPG2 and CPP-CPG2/CPG2-CPP Conjugates}

Sequences of CPG2 and the top 70 CPPs linked to the N- and C-terminus of CPG2 were submitted to the Foldrate server (http://www.csbio.sjtu.edu.cn/bioinf/FoldRate/) [95]. Foldrate provides an estimation on the time needed for proteins to fold into their tertiary structure by predicting $\ln \left(K_{\mathrm{f}}\right)$ constant of folding and half-folding time.

\subsection{Backbone Flexibility of CPG2 and CPP-CPG2/CPG2-CPP Conjugates}

Amino acid sequences of CPG2 and both $\mathrm{N}$ - and C-terminal conjugates of the top 70 CPPs and CPG2 were analyzed using the DynaMine server (http://dynamine.ibsquare.be/) [96]. DynaMine predicts the flexibility of each amino acid in a protein sequence by attributing values between $0-1$ to each residue. Zero accounts for complete flexibility and 1 for complete rigidity.

\subsection{Further Analyses for In Vivo Application}

\subsubsection{Analyses of CPP-CPG2 and CPG2-CPP Conjugates}

Sequences of 70 top CPP-CPG2 N-terminal and CPG2-CPP C-terminal conjugates were analyzed using AllergenFP V 1.0 (http://ddg-pharmfac.net/AllergenFP/) [97] to predict their potential allergenicity. Sequences of both $\mathrm{N}$ - and C-terminal conjugates of the top 70 CPPs and CPG2 were analyzed for potential immunogenicity by the VaxiJen V2.0 server (http://www.ddgpharmfac.net/vaxijen/VaxiJen/ VaxiJen.html) [98] considering bacteria as selected target organism. The half-life of CPG2 conjugated to the top 70 CPPs (both N- and C-terminal conjugates) was calculated using the ProtLifePred server (http://protein-n-end-rule.leadhoster.com/) in E. coli as the expression system. ProtLifePred server estimates the half-life of protein sequences based on the N-end rule considering ubiquitination $[99,100]$.

\subsubsection{Analyses of CPPs}

The top 70 CPPs were analyzed for their possible RBC lysis effect after in vivo administration by the HemoPI server (http://crdd.osdd.net/raghava/hemopi/) [101]. HemoPI server analyses submitted sequences using SVM based approach to predict their hemolysis potency by assigning each query a PROB score that ranges between 0-1. Zero is an indication of the lowest possibility of being hemolytic. In this study, the PROB score was set on 0.5 to determine hemolytic toxicity for each CPP. Potential toxicity of the top 70 CPPs was evaluated by ToxinPred server (http://crdd.osdd.net/raghava/toxinpred/ multi_submit.php) [102], using the server's default threshold (zero). Top 70 CPPs were checked for pro-inflammatory effect using the ProInflam server (http://metagenomics.iiserb.ac.in/proinflam/index. html) [103]. 


\subsection{Evaluation of CPP-CPG2/CPG2-CPP Conjugates Susceptibility to Human Proteases}

The susceptibility of the most promising CPP-CPG2 and CPG2-CPP conjugates to human proteases was evaluated using the Prosperous web server (http://prosperous.erc.monash.edu/) [104,105]. Out of 90 proteases available on the Prosperous server, 51 were human proteases according to MEROPS: the peptidase database [106]. These human proteases are categorized into four families, including aspartic proteases like cathespsin D and E, cysteine proteases like caspase 1 and 3, metalloproteases like matrix metallopeptidase 1,2,3, and serine proteases like thrombin and plasmin.

Prosperous assigns each cleavage site a probability score between 0.0 and 1.0. Zero is considered as the lowest possibility and 1.0 is estimated as the highest possibility of a position being recognized and cleaved by a protease. In this analysis, the FASTA sequences of CPG2 and 17 most promising CPP-CPG2/CPG2-CPP conjugates were submitted to Prosperous. A probability score of 0.700 and higher was considered significant for the susceptibility to human proteases. An overview of analyses employed in this study is shown as a bioinformatics flowchart below (Scheme 1).

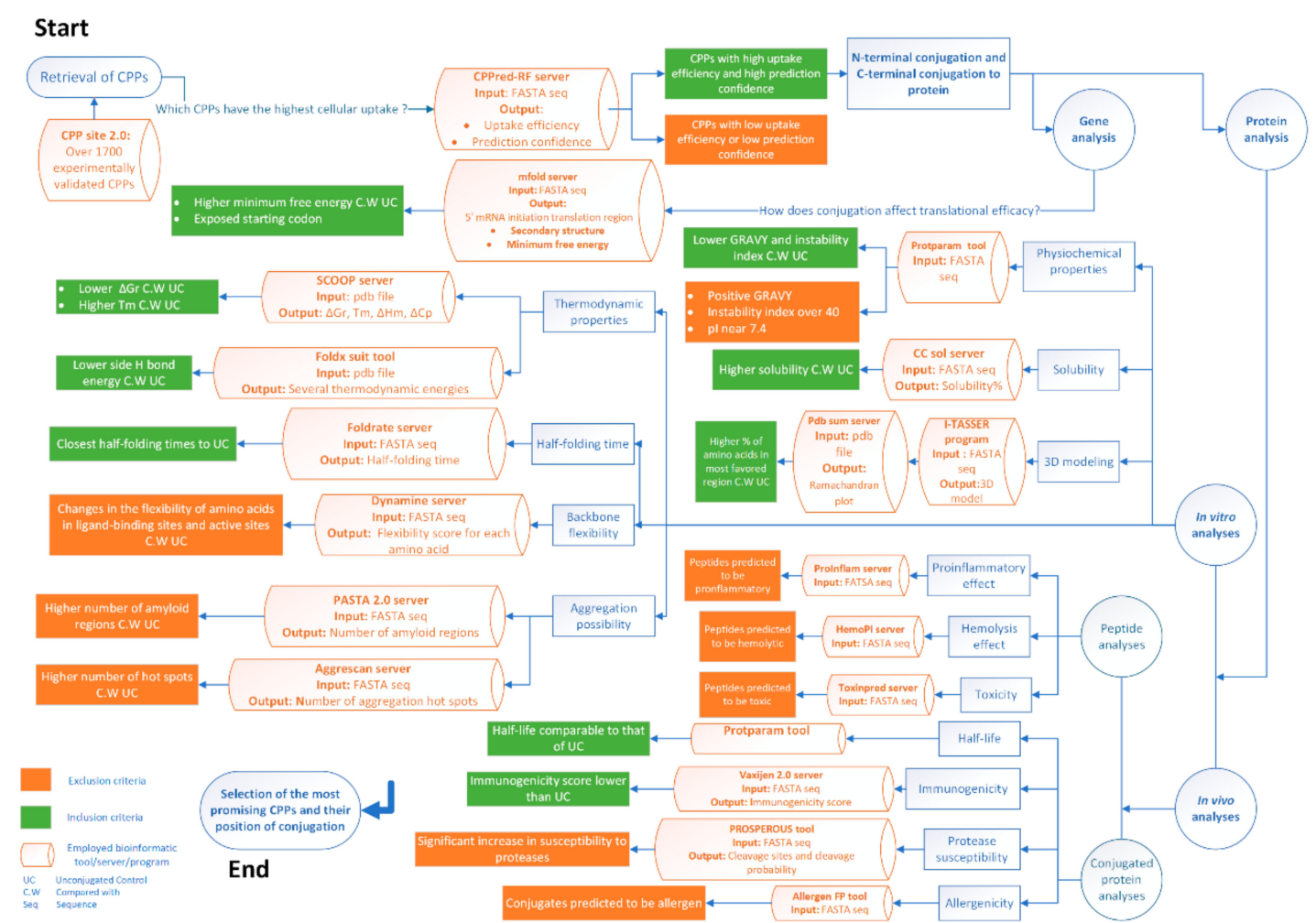

Scheme 1. A summary of the proposed workflow to select the most promising CPPs in conjugation with a protein.

\subsection{Statistical Analyses}

Unpaired t-test was used to test the significance between N-terminal (CPP-CPG2) and C-terminal (CPG2-CPP) values using GraphPad Prism 8 software (GraphPad Software, Inc. San Diego, CA, USA). $p<0.05$ indicated statistical significance.

\section{Conclusions}

Within this study, characterizing a high number of CPPs highlighted crucial factors necessary for the rational design of a CPP-protein chimera. This study presented a bioinformatics workflow applicable as a comprehensive approach useful to select CPP-cargo constructs for any therapeutic application. The addition of CPPs resulted in a higher probability of translation of mRNA into protein in about $74 \%$ of the $N$-terminal conjugates. Structurally more than $70 \%$ of the CPPs had $\alpha$-helix or $\beta$-sheet 
conformations in their secondary structure after conjugations, which results in higher penetration than for non-fused cargo. Addition of CPPs did not cause any significant negative changes regarding the stability of the target protein (thermodynamic stability and resistance to human proteases). Except for a few CPPs which might result in higher aggregation of the chimera, analysis of the physiochemical characteristics showed that the dominant number of CPPs linked to the cargo did not have any negative influence on the properties. Conjugation of CPPs did not negatively interfere with the solubility, even improved it. Computational analyses showed that allergenicity is not affected negatively and does not lead to limitations for injectable formulations. Flexibility analysis showed that in most conjugates, the addition of CPPs caused no major alterations in the overall enzyme flexibility. In all conjugates, the flexibility of the ligand-binding site after the addition of a CPP remained unchanged. However, stronger servers are needed for evaluation of the RBC hemolysis and pro-inflammatory effect of the peptide-protein conjugate. Concerning the position of conjugations, the $\mathrm{N}$-terminal linkage is preferred for the construction of CPP-CPG2 conjugates than the C-terminus CPG2-CPP homologs. The approach presented in this investigation is not limited to the CPP-glucarpidase case study but is generally applicable to any CPP-protein conjugate design. Hence, our study provides a platform for further in vitro and in vivo investigations, which should be considered regarding the advantages of computational analyses before designing any covalently conjugated CPP-protein construct.

Supplementary Materials: The followings are available online: Table S1: Result of CPPred-RF server analysis for all 1155 CPPs, Table S2: Result of analysis with mfold server for mRNA intiation translation region sequences of CPG2 and top 70 CPPs conjugated to $N$-terminal of CPG2 in PET 14b expression vector (All C-terminal conjugates have the same result as that of CPG2 itself), Table S3: Physiochemical properties of top 70 CPPs analyzed via ProtParam tool, Table S4: Physiochemical properties of top 70 CPG2-CPP C-terminal conjugates analyzed via ProtParam tool, Table S5: Analysis of 3D modeled structures of CPG2 and top 70 CPPs conjugated to CPG2 by PDBsum server, Table S6: Thermodynamic properties CPG2 and CPP-CPG2 conjugates calculated by the SCOOP sever, Table S7: Thermodynamic energies of CPG2 and CPP-CPG2 conjugates calculated by FoldX, Table S8: Analysis of aggregation possibility for CPG2 and top 70 CPPs conjugated to CPG2 by Pasta 2.0 and AGGRESCAN servers, Table S9: Half-life prediction for top 70 CPPs conjugated with CPG2, Table S10: Selection of top CPP candidates in conjugation to CPG2, Table S11: Shows whether the conjugates or CPG2 will be cleaved by respective proteases or not. The probability score of 0.700 was considered as significant, Table S12: Shows whether the conjugates will have increased risk of cleavage by each protease due to CPP addition compared with CPG2. Probability score of 0.700 was considered significant.

Author Contributions: Conceptualization, S.H.; methodology, S.H. and Y.B.; software, Y.B.; validation, S.H.; formal analysis, Y.B.; investigation, Y.B.; resources, S.H.; data curation, Y.B.; writing-original draft preparation, Y.B.; writing—review and editing, S.H.; visualization, Y.B.; supervision, S.H.; project administration, S.H.; funding acquisition, S.H.

Funding: This research was funded by Shiraz University of Medical Sciences, Shiraz, Iran under grant number 98-01-121-21066.

Acknowledgments: The support of Shiraz University of Medical Sciences is greatly acknowledged.

Conflicts of Interest: The authors declare no conflict of interest.

\section{References}

1. Sebbage, V. Cell-penetrating peptides and their therapeutic applications. Biosci. Horiz. 2009, 2, 64-72. [CrossRef]

2. Ramsey, J.D.; Flynn, N.H. Cell-penetrating peptides transport therapeutics into cells. Pharmacol. Ther. 2015, 154, 78-86. [CrossRef] [PubMed]

3. Frankel, A.D.; Pabo, C.O. Cellular uptake of the tat protein from human immunodeficiency virus. Cell 1988, 55, 1189-1193. [CrossRef]

4. Guidotti, G.; Brambilla, L.; Rossi, D. Cell-penetrating peptides: From basic research to clinics. Trends Pharmacol. Sci. 2017, 38, 406-424. [CrossRef] [PubMed]

5. Bechara, C.; Sagan, S. Cell-penetrating peptides: 20 years later, where do we stand? FEBS Lett. 2013, 587, 1693-1702. [CrossRef]

6. Borrelli, A.; Tornesello, A.; Tornesello, M.; Buonaguro, F. Cell penetrating peptides as molecular carriers for anti-cancer agents. Molecules 2018, 23, 295. [CrossRef] 
7. Kauffman, W.B.; Fuselier, T.; He, J.; Wimley, W.C. Mechanism Matters: A Taxonomy of Cell Penetrating Peptides. Trends Biochem. Sci. 2015, 40, 749-764. [CrossRef]

8. Kristensen, M.; Birch, D.; Mørck Nielsen, H. Applications and challenges for use of cell-penetrating peptides as delivery vectors for peptide and protein cargos. Int. J. Mol. Sci. 2016, 17, 185. [CrossRef]

9. Keller, A.-A.; Mussbach, F.; Breitling, R.; Hemmerich, P.; Schaefer, B.; Lorkowski, S.; Reissmann, S. Relationships between cargo, cell penetrating peptides and cell type for uptake of non-covalent complexes into live cells. Pharmaceuticals (Basel) 2013, 6, 184-203. [CrossRef]

10. Herce, H.D.; Deng, W.; Helma, J.; Leonhardt, H.; Cardoso, M.C. Visualization and targeted disruption of protein interactions in living cells. Nat. Commun. 2013, 4, 2660. [CrossRef]

11. Koshman, Y.E.; Waters, S.B.; Walker, L.A.; Los, T.; Tombe, P.d.; Goldspink, P.H.; Russell, B. Delivery and visualization of proteins conjugated to quantum dots in cardiac myocytes. J. Mol. Cell. Cardiol. 2008, 45, 853-856. [CrossRef]

12. Liang, J.F.; Yang, V.C. Insulin-cell penetrating peptide hybrids with improved intestinal absorption efficiency. Biochem. Biophys. Res. Commun. 2005, 335, 734-738. [CrossRef]

13. Chen, X.; Chen, J.; Fu, R.; Rao, P.; Weller, R.; Bradshaw, J.; Liu, S. Can the Cellular Internalization of Cargo Proteins Be Enhanced by Fusing a Tat Peptide in the Center of Proteins? A Fluorescence Study. J. Pharm. Sci. 2018, 107, 879-886. [CrossRef]

14. Patel, S.G.; Sayers, E.J.; He, L.; Narayan, R.; Williams, T.L.; Mills, E.M.; Allemann, R.K.; Luk, L.Y.P.; Jones, A.T.; Tsai, Y.-H. Cell-penetrating peptide sequence and modification dependent uptake and subcellular distribution of green florescent protein in different cell lines. Sci. Rep. 2019, 9, 6298. [CrossRef] [PubMed]

15. Courtois, F.; Schneider, C.P.; Agrawal, N.J.; Trout, B.L. Rational Design of Biobetters with Enhanced Stability. J. Pharm. Sci. 2015, 104, 2433-2440. [CrossRef] [PubMed]

16. Griswold, K.E.; Bailey-Kellogg, C. Design and engineering of deimmunized biotherapeutics. Curr. Opin. Struct. Biol. 2016, 39, 79-88. [CrossRef]

17. Agrawal, P.; Bhalla, S.; Usmani, S.S.; Singh, S.; Chaudhary, K.; Raghava, G.P.; Gautam, A. CPPsite 2.0: A repository of experimentally validated cell-penetrating peptides. Nucleic Acids Res. 2016, 44, D1098-D1103. [CrossRef]

18. Bolhassani, A.; Jafarzade, B.S.; Mardani, G. In vitro and in vivo delivery of therapeutic proteins using cell penetrating peptides. Peptides 2017, 87, 50-63. [CrossRef]

19. Hajiebrahimi, A.; Owji, H.; Hemmati, S. Genome-wide identification, functional prediction, and evolutionary analysis of the R2R3-MYB superfamily in Brassica napus. Genome 2017, 60, 797-814. [CrossRef]

20. Courtois, F.; Agrawal, N.J.; Lauer, T.M.; Trout, B.L. Rational design of therapeutic mAbs against aggregation through protein engineering and incorporation of glycosylation motifs applied to bevacizumab. $m A$ s 2016 , 8, 99-112. [CrossRef]

21. Schwartz, S.; Borner, K.; Muller, K.; Martus, P.; Fischer, L.; Korfel, A.; Auton, T.; Thiel, E. Glucarpidase (carboxypeptidase g2) intervention in adult and elderly cancer patients with renal dysfunction and delayed methotrexate elimination after high-dose methotrexate therapy. Oncologist 2007, 12, 1299-1308. [CrossRef] [PubMed]

22. Widemann, B.C.; Sung, E.; Anderson, L.; Salzer, W.L.; Balis, F.M.; Monitjo, K.S.; McCully, C.; Hawkins, M.; Adamson, P.C. Pharmacokinetics and metabolism of the methotrexate metabolite 2, 4-diamino-N(10)-methylpteroic acid. J. Pharmacol. Expe. Ther. 2000, 294, 894-901.

23. Green, J.M. Glucarpidase to combat toxic levels of methotrexate in patients. Ther. Clin. Risk Manag. 2012, 8, 403-413. [CrossRef]

24. Souza, C.; Pellosi, D.S.; Tedesco, A.C. Prodrugs for targeted cancer therapy. Expert Rev. Anticancer Ther. 2019. [CrossRef]

25. Hedley, D.; Ogilvie, L.; Springer, C. Carboxypeptidase G2-based gene-directed enzyme-prodrug therapy: A new weapon in the GDEPT armoury. Nat. Rev. Cancer 2007, 7, 870. [CrossRef] [PubMed]

26. Jeyaharan, D.; Brackstone, C.; Schouten, J.; Davis, P.; Dixon, A.M. Characterisation of the Carboxypeptidase G2 Catalytic Site and Design of New Inhibitors for Cancer Therapy. ChemBioChem 2018, 19, 1959-1968. [CrossRef] 
27. Ramsey, L.B.; Balis, F.M.; O’Brien, M.M.; Schmiegelow, K.; Pauley, J.L.; Bleyer, A.; Widemann, B.C.; Askenazi, D.; Bergeron, S.; Shirali, A.; et al. Consensus Guideline for Use of Glucarpidase in Patients with High-Dose Methotrexate Induced Acute Kidney Injury and Delayed Methotrexate Clearance. Oncologist 2018, 23, 52-61. [CrossRef]

28. Sadeghian, I.; Khalvati, B.; Ghasemi, Y.; Hemmati, S. TAT-mediated intracellular delivery of carboxypeptidase G2 protects against methotrexate-induced cell death in HepG2 cells. Toxicol. Appl. Pharmacol. 2018, 346, 9-18. [CrossRef]

29. Jha, D.; Mishra, R.; Gottschalk, S.; Wiesmuller, K.H.; Ugurbil, K.; Maier, M.E.; Engelmann, J. CyLoP-1: A novel cysteine-rich cell-penetrating peptide for cytosolic delivery of cargoes. Bioconjug. Chem. 2011, 22, 319-328. [CrossRef]

30. Jones, S.W.; Christison, R.; Bundell, K.; Voyce, C.J.; Brockbank, S.M.; Newham, P.; Lindsay, M.A. Characterisation of cell-penetrating peptide-mediated peptide delivery. Br. J. Pharmacol. 2005, 145, 1093-1102. [CrossRef]

31. Fischer, P.M.; Zhelev, N.Z.; Wang, S.; Melville, J.E.; Fahraeus, R.; Lane, D.P. Structure-activity relationship of truncated and substituted analogues of the intracellular delivery vector Penetratin. J. Pept. Res. 2000, 55, 163-172. [CrossRef] [PubMed]

32. Hansen, M.; Kilk, K.; Langel, U. Predicting cell-penetrating peptides. Adv. Drug Deliv. Rev. 2008, 60, 572-579. [CrossRef] [PubMed]

33. Derossi, D.; Calvet, S.; Trembleau, A.; Brunissen, A.; Chassaing, G.; Prochiantz, A. Cell internalization of the third helix of the Antennapedia homeodomain is receptor-independent. J. Biol. Chem. 1996, 271, 18188-18193. [CrossRef] [PubMed]

34. Noguchi, H.; Kaneto, H.; Weir, G.C.; Bonner-Weir, S. PDX-1 protein containing its own antennapedia-like protein transduction domain can transduce pancreatic duct and islet cells. Diabetes 2003, 52, 1732-1737. [CrossRef]

35. Kondo, E.; Saito, K.; Tashiro, Y.; Kamide, K.; Uno, S.; Furuya, T.; Mashita, M.; Nakajima, K.; Tsumuraya, T.; Kobayashi, N.; et al. Tumour lineage-homing cell-penetrating peptides as anticancer molecular delivery systems. Nat. Commun. 2012, 3, 951. [CrossRef]

36. Kamide, K.; Nakakubo, H.; Uno, S.; Fukamizu, A. Isolation of novel cell-penetrating peptides from a random peptide library using in vitro virus and their modifications. Int. J. Mol. Med. 2010, 25, 41-51. [CrossRef]

37. Gomez, J.A.; Chen, J.; Ngo, J.; Hajkova, D.; Yeh, I.J.; Gama, V.; Miyagi, M.; Matsuyama, S. Cell-Penetrating Penta-Peptides (CPP5s): Measurement of Cell Entry and Protein-Transduction Activity. Pharmaceuticals (Basel) 2010, 3, 3594-3613. [CrossRef]

38. Elmquist, A.; Hansen, M.; Langel, U. Structure-activity relationship study of the cell-penetrating peptide pVEC. Biochim. Biophys. Acta 2006, 1758, 721-729. [CrossRef]

39. Cohen-Avrahami, M.; Shames, A.I.; Ottaviani, M.F.; Aserin, A.; Garti, N. HIV-TAT enhances the transdermal delivery of NSAID drugs from liquid crystalline mesophases. J. Phys. Chem. B 2014, 118, 6277-6287. [CrossRef]

40. Futaki, S.; Suzuki, T.; Ohashi, W.; Yagami, T.; Tanaka, S.; Ueda, K.; Sugiura, Y. Arginine-rich peptides. An abundant source of membrane-permeable peptides having potential as carriers for intracellular protein delivery. J. Biol. Chem. 2001, 276, 5836-5840. [CrossRef]

41. Nakase, I.; Hirose, H.; Tanaka, G.; Tadokoro, A.; Kobayashi, S.; Takeuchi, T.; Futaki, S. Cell-surface accumulation of flock house virus-derived peptide leads to efficient internalization via macropinocytosis. Mol. Ther. 2009, 17, 1868-1876. [CrossRef] [PubMed]

42. Wender, P.A.; Mitchell, D.J.; Pattabiraman, K.; Pelkey, E.T.; Steinman, L.; Rothbard, J.B. The design, synthesis, and evaluation of molecules that enable or enhance cellular uptake: Peptoid molecular transporters. Proc. Natl. Acad. Sci. USA 2000, 97, 13003-13008. [CrossRef] [PubMed]

43. Johansson, H.J.; El-Andaloussi, S.; Holm, T.; Mae, M.; Janes, J.; Maimets, T.; Langel, U. Characterization of a novel cytotoxic cell-penetrating peptide derived from p14ARF protein. Mol. Ther. 2008, 16, 115-123. [CrossRef]

44. El-Andaloussi, S.; Johansson, H.J.; Holm, T.; Langel, U. A novel cell-penetrating peptide, M918, for efficient delivery of proteins and peptide nucleic acids. Mol. Ther. 2007, 15, 1820-1826. [CrossRef] 
45. Scheller, A.; Oehlke, J.; Wiesner, B.; Dathe, M.; Krause, E.; Beyermann, M.; Melzig, M.; Bienert, M. Structural requirements for cellular uptake of alpha-helical amphipathic peptides. J. Pept. Sci. 1999, 5, 185-194. [CrossRef]

46. Fernandez-Carneado, J.; Kogan, M.J.; Pujals, S.; Giralt, E. Amphipathic peptides and drug delivery. Biopolymers 2004, 76, 196-203. [CrossRef]

47. Shinde, A.; Feher, K.M.; Hu, C.; Slowinska, K. Peptide internalization enabled by folding: Triple helical cell-penetrating peptides. J. Pept. Sci. 2015, 21, 77-84. [CrossRef]

48. Eiriksdottir, E.; Konate, K.; Langel, U.; Divita, G.; Deshayes, S. Secondary structure of cell-penetrating peptides controls membrane interaction and insertion. Biochim. Biophys. Acta 2010, 1798, 1119-1128. [CrossRef]

49. Zhu, F.; Liu, F.; Wu, B.; He, B. Efficient extracellular expression of metalloprotease for Z-aspartame synthesis. J. Agric. Food Chem. 2016, 64, 9631-9638. [CrossRef]

50. Owji, H.; Hemmati, S. A comprehensive in silico characterization of bacterial signal peptides for the excretory production of Anabaena variabilis phenylalanine ammonia lyase in Escherichia coli. 3 Biotech 2018, 8, 488. [CrossRef]

51. Kramer, R.M.; Shende, V.R.; Motl, N.; Pace, C.N.; Scholtz, J.M. Toward a molecular understanding of protein solubility: Increased negative surface charge correlates with increased solubility. Biophys. J. 2012, 102, 1907-1915. [CrossRef]

52. Dubikovskaya, E.A.; Thorne, S.H.; Pillow, T.H.; Contag, C.H.; Wender, P.A. Overcoming multidrug resistance of small-molecule therapeutics through conjugation with releasable octaarginine transporters. Proc. Natl. Acad. Sci. USA 2008, 105, 12128-12133. [CrossRef]

53. Duan, Z.; Chen, C.; Qin, J.; Liu, Q.; Wang, Q.; Xu, X.; Wang, J. Cell-penetrating peptide conjugates to enhance the antitumor effect of paclitaxel on drug-resistant lung cancer. Drug Deliv. 2017, 24, 752-764. [CrossRef]

54. Kristensen, M.; de Groot, A.M.; Berthelsen, J.; Franzyk, H.; Sijts, A.; Nielsen, H.M. Conjugation of cell-penetrating peptides to parathyroid hormone affects its structure, potency, and transepithelial permeation. Bioconjug. Chem. 2015, 26, 477-488. [CrossRef]

55. Rahmatabadi, S.S.; Sadeghian, I.; Ghasemi, Y.; Sakhteman, A.; Hemmati, S. Identification and characterization of a sterically robust phenylalanine ammonia-lyase among 481 natural isoforms through association of in silico and in vitro studies. Enzyme Microb. Technol. 2019, 122, 36-54. [CrossRef]

56. Sadeghian, I.; Rezaie, Z.; Rahmatabadi, S.S.; Hemmati, S. Biochemical insights into a novel thermo/organo tolerant bilirubin oxidase from Thermosediminibacter oceani and its application in dye decolorization. Process Biochem. 2019. [CrossRef]

57. Edgeworth, M.J.; Phillips, J.J.; Lowe, D.C.; Kippen, A.D.; Higazi, D.R.; Scrivens, J.H. Global and local conformation of human IgG antibody variants rationalizes loss of thermodynamic stability. Angew. Chem. Int. Ed. Engl. 2015, 54, 15156-15159. [CrossRef]

58. Pucci, F.; Rooman, M. Stability curve prediction of homologous proteins using temperature-dependent statistical potentials. PLoS Comput. Biol. 2014, 10, e1003689. [CrossRef]

59. Ahmed, A.B.; Kajava, A.V. Breaking the amyloidogenicity code: Methods to predict amyloids from amino acid sequence. FEBS Lett. 2013, 587, 1089-1095. [CrossRef]

60. Wang, W. Instability, stabilization, and formulation of liquid protein pharmaceuticals. Int. J. Pharm. 1999, 185, 129-188. [CrossRef]

61. Fink, A.L. Protein aggregation: Folding aggregates, inclusion bodies and amyloid. Fold. Des. 1998, 3, R9-R23. [CrossRef]

62. DuBay, K.F.; Pawar, A.P.; Chiti, F.; Zurdo, J.; Dobson, C.M.; Vendruscolo, M. Prediction of the absolute aggregation rates of amyloidogenic polypeptide chains. J. Mol. Biol. 2004, 341, 1317-1326. [CrossRef] [PubMed]

63. Conchillo-Solé, O.; de Groot, N.S.; Avilés, F.X.; Vendrell, J.; Daura, X.; Ventura, S. AGGRESCAN: A server for the prediction and evaluation of" hot spots" of aggregation in polypeptides. BMC Bioinformatics 2007, 8, 65. [CrossRef] [PubMed]

64. Garbuzynskiy, S.O.; Lobanov, M.Y.; Galzitskaya, O.V. FoldAmyloid: A method of prediction of amyloidogenic regions from protein sequence. Bioinformatics 2009, 26, 326-332. [CrossRef] [PubMed]

65. Echols, N.; Milburn, D.; Gerstein, M. MolMovDB: Analysis and visualization of conformational change and structural flexibility. Nucleic Acids Res. 2003, 31, 478-482. [CrossRef] [PubMed] 
66. Clark, J.J.; Benson, M.L.; Smith, R.D.; Carlson, H.A. Inherent versus induced protein flexibility: Comparisons within and between apo and holo structures. PLoS Comput. Biol. 2019, 15, e1006705. [CrossRef]

67. Hemmati, S.; Schneider, B.; Schmidt, T.J.; Federolf, K.; Alfermann, A.W.; Fuss, E. Justicidin B 7-hydroxylase, a cytochrome P450 monooxygenase from cell cultures of Linum perenne Himmelszelt involved in the biosynthesis of diphyllin. Phytochemistry 2007, 68, 2736-2743. [CrossRef]

68. Rizzuti, M.; Nizzardo, M.; Zanetta, C.; Ramirez, A.; Corti, S. Therapeutic applications of the cell-penetrating HIV-1 Tat peptide. Drug Discov. Today 2015, 20, 76-85. [CrossRef]

69. Dupont, E.; Prochiantz, A.; Joliot, A. Penetratin story: An overview. In Cell-Penetrating Peptides; Langel, Ü, Ed.; Cell-Penetrating Peptides. Methods in Molecular Biology; Humana Press: New York, NY, USA, 2015; Volume 1324, pp. 29-37. [CrossRef]

70. Kalafatovic, D.; Giralt, E. Cell-penetrating peptides: Design strategies beyond primary structure and amphipathicity. Molecules 2017, 22, 1929. [CrossRef]

71. Gomez, J.A.; Gama, V.; Yoshida, T.; Sun, W.; Hayes, P.; Leskov, K.; Boothman, D.; Matsuyama, S. Bax-inhibiting peptides derived from Ku70 and cell-penetrating pentapeptides. Biochem. Soc. Trans. 2007, 35, 797-801. [CrossRef]

72. Li, Y.; Yokota, T.; Gama, V.; Yoshida, T.; Gomez, J.A.; Ishikawa, K.; Sasaguri, H.; Cohen, H.Y.; Sinclair, D.A.; Mizusawa, H.; et al. Bax-inhibiting peptide protects cells from polyglutamine toxicity caused by Ku70 acetylation. Cell Death Differ. 2007, 14, 2058-2067. [CrossRef] [PubMed]

73. Jensen, K.; WuWong, D.J.; Wong, S.; Matsuyama, M.; Matsuyama, S. Pharmacological inhibition of Bax-induced cell death: Bax-inhibiting peptides and small compounds inhibiting Bax. Exp. Biol. Med. 2019, 244, 621-629. [CrossRef] [PubMed]

74. Böttger, R.; Hoffmann, R.; Knappe, D. Differential stability of therapeutic peptides with different proteolytic cleavage sites in blood, plasma and serum. PloS ONE 2017, 12, e0178943. [CrossRef] [PubMed]

75. Yachnin, B.J.; Khare, S.D. Engineering carboxypeptidase G2 circular permutations for the design of an autoinhibited enzyme. Protein Eng. Des. Sel. 2017, 30, 321-331. [CrossRef]

76. AlQahtani, A.D.; Al-mansoori, L.; Bashraheel, S.S.; Rashidi, F.B.; Al-Yafei, A.; Elsinga, P.; Domling, A.; Goda, S.K. Production of "biobetter" glucarpidase variants to improve drug detoxification and antibody directed enzyme prodrug therapy for cancer treatment. Eur. J. Pharm. Sci. 2019, 127, 79-91. [CrossRef]

77. AlQahtani, A.D.; O'Connor, D.; Domling, A.; Goda, S.K. Strategies for the production of long-acting therapeutics and efficient drug delivery for cancer treatment. Biomed. Pharmacother. 2019, 113, 108750. [CrossRef]

78. Erazo-Oliveras, A.; Muthukrishnan, N.; Baker, R.; Wang, T.-Y.; Pellois, J.-P. Improving the Endosomal Escape of Cell-Penetrating Peptides and Their Cargos: Strategies and Challenges. Pharmaceuticals 2012, 5, 1177-1209. [CrossRef]

79. Rydström, A.; Deshayes, S.; Konate, K.; Crombez, L.; Padari, K.; Boukhaddaoui, H.; Aldrian, G.; Pooga, M.; Divita, G. Direct translocation as major cellular uptake for CADY self-assembling peptide-based nanoparticles. PloS ONE 2011, 6, e25924. [CrossRef]

80. Hayashi, Y.; Yamauchi, J.; Khalil, I.A.; Kajimoto, K.; Akita, H.; Harashima, H. Cell penetrating peptide-mediated systemic siRNA delivery to the liver. Int. J. Pharm. 2011, 419, 308-313. [CrossRef]

81. El-Sayed, N.S.; Shirazi, A.N.; Sajid, M.I.; Park, S.E.; Parang, K.; Tiwari, R.K. Synthesis and Antiproliferative Activities of Conjugates of Paclitaxel and Camptothecin with a Cyclic Cell-Penetrating Peptide. Molecules 2019, 24, 1427. [CrossRef]

82. Shirazi, A.N.; Mozaffari, S.; Sherpa, R.T.; Tiwari, R.; Parang, K. Efficient Intracellular Delivery of Cell-Impermeable Cargo Molecules by Peptides Containing Tryptophan and Histidine. Molecules 2018, 23, 1536. [CrossRef]

83. Najjar, K.; Erazo-Oliveras, A.; Brock, D.J.; Wang, T.-Y.; Pellois, J.-P. An 1- to d-Amino Acid Conversion in an Endosomolytic Analog of the Cell-penetrating Peptide TAT Influences Proteolytic Stability, Endocytic Uptake, and Endosomal Escape. J. Biol. Chem. 2017, 292, 847-861. [CrossRef]

84. Wei, L.; Xing, P.; Su, R.; Shi, G.; Ma, Z.S.; Zou, Q. CPPred-RF: A Sequence-based Predictor for Identifying Cell-Penetrating Peptides and Their Uptake Efficiency. J. Proteome Res. 2017, 16, 2044-2053. [CrossRef]

85. Zuker, M. Mfold web server for nucleic acid folding and hybridization prediction. Nucleic Acids Res. 2003, 31, 3406-3415. [CrossRef] 
86. Gasteiger, E.; Hoogland, C.; Gattiker, A.; Wilkins, M.R.; Appel, R.D.; Bairoch, A. Protein identification and analysis tools on the ExPASy server. In The Proteomics Protocols Handbook, 1st ed.; Walker, J.M., Ed.; Humana Press: Hatfield, UK, 2005; pp. 571-607. [CrossRef]

87. Agostini, F.; Vendruscolo, M.; Tartaglia, G.G. Sequence-based prediction of protein solubility. J. Mol. Biol. 2012, 421, 237-241. [CrossRef]

88. Roy, A.; Kucukural, A.; Zhang, Y. I-TASSER: A unified platform for automated protein structure and function prediction. Nat. Protoc. 2010, 5, 725. [CrossRef]

89. Zhang, Y. I-TASSER server for protein 3D structure prediction. BMC Bioinformatics 2008, 9, 40. [CrossRef]

90. Laskowski, R.A. Enhancing the functional annotation of PDB structures in PDBsum using key figures extracted from the literature. Bioinformatics 2007, 23, 1824-1827. [CrossRef]

91. Laskowski, R.A.; Jabłońska, J.; Pravda, L.; Vařeková, R.S.; Thornton, J.M. PDBsum: Structural summaries of PDB entries. Protein Sci. 2018, 27, 129-134. [CrossRef]

92. Pucci, F.; Kwasigroch, J.M.; Rooman, M. SCooP: An accurate and fast predictor of protein stability curves as a function of temperature. Bioinformatics 2017, 33, 3415-3422. [CrossRef]

93. Schymkowitz, J.; Borg, J.; Stricher, F.; Nys, R.; Rousseau, F.; Serrano, L. The FoldX web server: An online force field. Nucleic Acids Res. 2005, 33, W382-W388. [CrossRef]

94. Walsh, I.; Seno, F.; Tosatto, S.C.; Trovato, A. PASTA 2.0: An improved server for protein aggregation prediction. Nucleic Acids Res. 2014, 42, W301-W307. [CrossRef]

95. Chou, K.-C.; Shen, H.-B. FoldRate: A web-server for predicting protein folding rates from primary sequence. Open Bioinforma. J. 2009, 3, 31-50. [CrossRef]

96. Cilia, E.; Pancsa, R.; Tompa, P.; Lenaerts, T.; Vranken, W.F. The DynaMine webserver: Predicting protein dynamics from sequence. Nucleic Acids Res. 2014, 42, W264-W270. [CrossRef]

97. Dimitrov, I.; Naneva, L.; Doytchinova, I.; Bangov, I. AllergenFP: Allergenicity prediction by descriptor fingerprints. Bioinformatics 2013, 30, 846-851. [CrossRef]

98. Doytchinova, I.A.; Flower, D.R. VaxiJen: A server for prediction of protective antigens, tumour antigens and subunit vaccines. BMC Bioinformatics 2007, 8, 4. [CrossRef]

99. Bachmair, A.; Finley, D.; Varshavsky, A. In vivo half-life of a protein is a function of its amino-terminal residue. Science 1986, 234, 179-186. [CrossRef]

100. Varshavsky, A. The N-end rule pathway of protein degradation. Genes Cells 1997, 2, 13-28. [CrossRef]

101. Chaudhary, K.; Kumar, R.; Singh, S.; Tuknait, A.; Gautam, A.; Mathur, D.; Anand, P.; Varshney, G.C.; Raghava, G.P.S. A Web Server and Mobile App for Computing Hemolytic Potency of Peptides. Sci. Rep. 2016, 6, 22843. [CrossRef]

102. Gupta, S.; Kapoor, P.; Chaudhary, K.; Gautam, A.; Kumar, R.; Raghava, G.P.; Open Source Drug Discovery Consortium. In silico approach for predicting toxicity of peptides and proteins. PloS ONE 2013, 8, e73957. [CrossRef]

103. Gupta, S.; Madhu, M.K.; Sharma, A.K.; Sharma, V.K. ProInflam: A webserver for the prediction of proinflammatory antigenicity of peptides and proteins. J. Transl. Med. 2016, 14, 178. [CrossRef]

104. Song, J.; Li, F.; Leier, A.; Marquez-Lago, T.T.; Akutsu, T.; Haffari, G.; Chou, K.-C.; Webb, G.I.; Pike, R.N. PROSPERous: High-throughput prediction of substrate cleavage sites for 90 proteases with improved accuracy. Bioinformatics 2017, 34, 684-687. [CrossRef]

105. Li, F.; Wang, Y.; Li, C.; Marquez-Lago, T.T.; Leier, A.; Rawlings, N.D.; Haffari, G.; Revote, J.; Akutsu, T.; Chou, K.-C. Twenty years of bioinformatics research for protease-specific substrate and cleavage site prediction: A comprehensive revisit and benchmarking of existing methods. Brief. Bioinform. 2018, bby077. [CrossRef] [PubMed]

106. Rawlings, N.D.; Barrett, A.J.; Finn, R. Twenty years of the MEROPS database of proteolytic enzymes, their substrates and inhibitors. Nucleic Acids Res. 2015, 44, D343-D350. [CrossRef] [PubMed]

Sample Availability: Not available.

(C) 2019 by the authors. Licensee MDPI, Basel, Switzerland. This article is an open access article distributed under the terms and conditions of the Creative Commons Attribution (CC BY) license (http://creativecommons.org/licenses/by/4.0/). 